\title{
How and when amnesty during conflict affects conflict termination
}

Lesley-Ann Daniels

1daniels@ibei.org

Journal of Conflict Resolution, online first 2020,

https://doi.org/10.1177/0022002720909884

\begin{abstract}
In the difficult process of ending civil wars, granting amnesty during conflict is seen as a useful option, with an underpinning assumption that trading justice for peace is effective. However, is the case? This article tries to bring some clarity to when and how amnesty given during conflict has an impact. Amnesty should have different effects on diverse conflict endings: negotiated settlement, rebel victory, government victory or conflict reduction. The article also disaggregates amnesties to test direct impacts as an incentive or through reducing the commitment problem, and indirect effects that give military advantage to the government. Using a cross-national dataset of amnesties in dyadic conflicts from 1975 to 2011, the research finds that amnesty's strongest effect is, surprisingly, not as an incentive but rather to reduce commitment problems. It can lead to negotiated settlements but also government military advantage. The results have implications for negotiations and conflict resolution.
\end{abstract}

Key words: civil war, amnesty, conflict termination, bargaining, transitional justice, commitment problems

Acknowledgements: The author would like to thank the editor and reviewers, Abel EscribàFolch, Scott Gates, Rafael Grasa, Louise Mallinder, Leigh A. Payne, Jack Snyder and Nils B. Weidmann for their comments. She also thanks the International Catalan Institute for Peace and the AXA Research Fund for financial support. 


\section{Introduction}

The Algerian civil war was known as the 'dirty war' for its brutality against civilians, journalists, foreigners, and other factions, as well as the state. The Islamic Salvation Front (FIS) fought a violent civil war after the government cancelled results of elections in 1991, under pressure from the military. The rebels splintered into the Islamic Salvation Army (AIS) and the more hard-line Armed Islamic Group (GIA) and both committed atrocities. Between 44,000 and 150,000 people died (Hagelstein 2008; Schulhofer-Wohl 2007).

During the course of the conflict, the government repeatedly used amnesties. For example, an amnesty law in 1999 was included as part of the negotiations with the more moderate AIS. Press reports suggest about 1,500 fighters took up this amnesty (Human Rights Watch 2001). When the six-month limit to this law ended, President Bouteflika issued a further amnesty by presidential decree. This second provision was more generous and allowed amnesty for all crimes, even the most heinous. The leaders of AIS, along with a breakaway group from GIA, decided to end their conflict and between 2,000 and 4,000 more fighters took advantage of this amnesty. The rump of the GIA was slowly overwhelmed by military operations and by 2002 had effectively disappeared (Mallinder 2009; Tlemcani 2008).

The so-called peace versus justice debate hinges on the idea that the unpalatable sacrifice of justice is necessary for peace, and there has been a large literature written on the normative considerations involved (for example, Roht-Arriaza, 2006; Skaar, 2013; Sriram, 2004; Vinjamuri \& Snyder, 2004). Although there has been a strong international turn against amnesties (Orentlicher, 1991, 1996; UN Secretary-General, 1999), the use of amnesty has been remarkably constant, as shown in Figure 1. Indeed, recently there has been a reassertion of the advantages of amnesties (Putnam 2002; Snyder and Vinjamuri 2003; Mallinder 2008; Freeman 2009; Mendez 2012; Patterson 2012). Amnesties have even been advocated as acceptable under the responsibility to protect, with the argument that the first priority must be to save lives and that ending the conflict swiftly will bring a lower overall death toll (Anonymous 1996). Underpinning these arguments is an assumption that amnesties are effective in helping bring conflicts to a close. Given the stakes and the moral hazard involved, surely we want to know whether the granting of an amnesty actually helps to make peace? However, 'there is much less empirical certainty about amnesty's benefits than many realists are ready to concede' (Freeman, 2009: 7). 


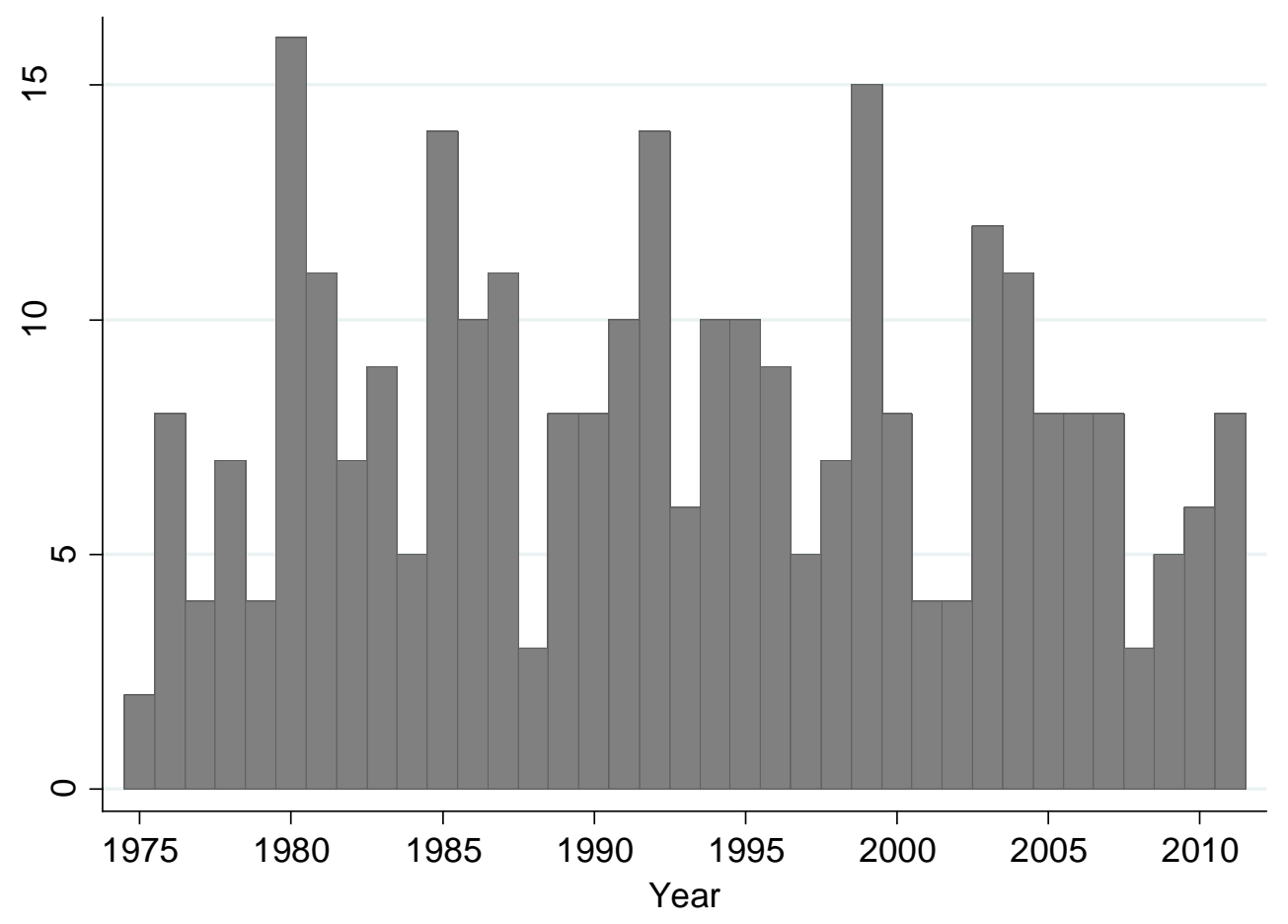

Figure 1: Amnesties by year 1975-2011

To address this problem, researchers are increasingly generating cross-national analyses of justice mechanisms and civil war (Binningsbø et al. 2012; Reiter, Olsen, and Payne 2012; Olsen, Payne, and Reiter 2010; Dancy 2018). Much of this research focuses on the impact of amnesty after civil war, but there is increasing recognition that the majority of amnesties occur during civil wars (Olsen, Payne, and Reiter 2010; Loyle and Binningsbø 2018) and I add to this literature. During the period under study, 1975-2011, I register 269 amnesties during conflict, while a dataset of post-conflict amnesties for the same period registers only 68 amnesties (Binningsbø et al. 2012). In most years, amnesty is given in more than $10 \%$ of conflicts. Such amnesties are important in terms of determining the conflict ending and affecting what options are available during the conflict settlement and also the post-conflict period.

I put forward two advances to the current literature. To date, research has shown surprisingly little effect by amnesty on a simple measure of conflict termination. The first contribution is therefore to disaggregate conflict endings. We can expect amnesty to have different effects on different forms of conflict termination, i.e. negotiated settlement, rebel victory, government victory, or conflict reduction. The second contribution is to draw on the transitional justice and civil war literatures to theorize different ways in which amnesty can have effects. Amnesties are given for a range of purposes. They can be used to tempt leaders to abandon armed conflict; they are sometimes given to offer leaders security during a process of negotiations; they can be offered repeatedly to display the government's intentions to deal in good faith; or they can be used to leapfrog the leadership and suck away rebel followers. I examine two mechanisms by which amnesty can have an effect on conflict endings and I propose that these different mechanisms make use of different forms of 
amnesty to best achieve the aims desired. One way in which amnesty can have an impact is as an incentive for rebels to abandon conflict. Amnesties that excuse atrocious crimes can be a more compelling incentive and I examine whether they have stronger effects. Drawing on bargaining theory, another way in which amnesty can influence outcomes is as a means to reduce information asymmetries and reduce commitment problems. A formal amnesty is more trustworthy than an informal offer and again I test for a difference in outcomes. As well as the direct effects in encouraging fighters to give up fighting, thus fragmenting rebel groups or removing groups from the conflict, amnesties have indirect effects on the groups that carry on fighting. Such groups are left exposed and the government is able to concentrate their forces on the remaining fighters. In these circumstances, we can expect the conflict to end to the government's advantage.

I test these predictions on cross-national data on amnesties in government-rebel group dyadic conflicts from 1975 to 2011 using a competing risks model of conflict endings. The results show that amnesties have effects in nuanced ways. Amnesty has a weak impact, if any, as an incentive, since negotiated settlement is no more likely after an amnesty or a more generous amnesty, i.e. one that forgives heinous crimes. Rather amnesty increases the likelihood of negotiated settlement when it is given as a formal amnesty, which can reduce information asymmetries and reduce commitment problems. Amnesties also have indirect effects by reducing groups and so weakening the opposition, allowing the government to gain a military advantage.

These results extend the literature by showing that amnesty does have effects on conflict endings, but on specific endings. The results also make a contribution in finding no support for the widespread idea in the transitional justice literature that amnesty works as a way to buy off unpalatable leaders. Rather, the largest effect of amnesty is when it reduces the commitment problem. This result has implications for peace negotiators and shows that there is a role in conflict termination for amnesties that respect international law.

\section{Theoretical Framework}

Explanations for the termination of civil wars is still an open topic. Many civil wars drag on, even though information revealed by battlefield successes and losses should make it easy for parties to come to a deal and avoid further costly conflict (Fearon 2013; Nilsson 2008). When either side is significantly stronger than the other, it has a belief that it can fight to win, which is its preferred option (Mason, Weingarten Jnr, and Fett 1999; Mason and Fett 1996; Melin and Svensson 2009; Clayton 2013). However, when relative strength is more balanced neither side can expect an outright victory, at the same time, costs accumulate (Clayton 2013; Mason, Weingarten Jnr, and Fett 1999). Governments that wish to change the dynamics of a conflict have a range of military options - military surges, decapitation of the rebel leadership, etc., (Johnston 2012; Biddle, Friedman, and Shapiro 2012; Ryckman 2017). This research looks at a non-military option: amnesty. I take the definition of amnesty from Freeman: "an extraordinary legal measure whose primary function is to remove the prospect and consequences of criminal liability for designated individuals or classes of persons in 
respect of designated types of offenses irrespective of whether the persons concerned have been tried for such offenses in a court of law" (Freeman, 2009: 13).

Giving amnesty has advantages for the government. Firstly, amnesty can be a lowcost way to change the dynamic of a conflict without having to use military means and risk troops. Secondly, amnesty can be used as a way to end the conflict now rather than later. Amnesties can be a take-it-or-leave-it offer with time limits in order to end the conflict quickly and so avoid further costs mounting for the government. Amnesty can also be beneficial as a way to break a deadlock. Further advantages for the government are that amnesties test the rebels' commitment and the rebels' response reveals information about group resolve and unity (Fearon 1995, 2013).

The justice versus peace debate hinges around the idea that giving amnesty to perpetrators is repugnant but a price worth paying to get to a peaceful settlement. To give just one example, many feel revulsion at the offer of amnesty in 2006 to the Lord's Resistance Army leader, Joseph Kony, while others argue that threatening him with trials had a worse net effect, since this move backed him into a corner where he had no choice but to fight in order to ensure his own freedom (Schomerus and Ogwaro 2010). ${ }^{1}$ The empirical evidence to date suggests that amnesty does not bring the expected results. Olsen, Payne and Reiter (2010b) and Reiter (2014) use descriptive evidence to suggest that amnesty does not help end conflict, while Loyle and Binningsbø (2018) find that measures that address rebels' motivation (including amnesties) do not help end conflict, though they group transitional justice measures together and do not consider amnesties separately. The most developed theoretical examination to date is that of Dancy (2018), who also finds that that amnesties during conflict do not make the conflict end sooner. He argues that amnesty during conflict is a "noisy signal" that gets lost in wartime bargaining. Indeed, rather than reducing the commitment problem, in the absence of complete information amnesties can lead adversaries to think they are being "suckered" and amnesties are thus an "instrument of asymmetric information" (p. 398, emphasis in original).

However, to date, research has looked at conflict ending as a homogenous category and assumed one single mechanism. I examine the alternative conflict endings of negotiated settlement, rebel victory, government victory or conflict reduction, as against continued conflict. I start with the understanding that amnesties are given for different reasons and I separate possible mechanisms. In doing this, the article draws on both the individualist perspective of the transitional justice literature and on bargaining theory and rational choice from the conflict resolution literature.

\section{Direct effects of amnesty}

The transitional justice literature views amnesty as a tradeoff for peace, a view that is underpinned by the idea that amnesty is an incentive. We can take as a starting point the view that the use of violence is a rational act (Fearon and Laitin 2003; Kalyvas 2006). Adversaries choose whether to end violence and reach a settlement based on bounded rational choice

\footnotetext{
${ }^{1}$ The government of Uganda referred the case in December 2003 to the International Criminal Court, which issued sealed warrants of arrest in July 2005. These warrants were unsealed in October of that year.
} 
theory where actors use the information available to take the decision that has the most benefits and least costs for them. In the context of ending civil wars, agreement is reached when the government and the rebels can find a meeting point in their demands (Fearon 1995, 2004 , 2013). This theory would predict that offering amnesties to perpetrators is an incentive that should change their decision calculus, by increasing the attractiveness of the pact and/or reducing the costs of surrender (Mason, Weingarten Jnr, and Fett 1999).

The advantages of amnesty may be specific to the circumstances of the leadership, however, there are some generalizable advantages. For example, amnesty can allow access to political power or military leadership. The M-19 guerrilla group in 1990 in Colombia could only compete in elections and take political office because their crimes were recognized as political crimes and amnestied; the leader of the Communist Party of Nepal rebel group was amnestied in 2006 and later became Prime Minister of Nepal; the amnestied leader of the RENAMO rebel group in Mozambique contested three presidential elections; and the amnestied leaders of the Free Aceh Movement in Aceh in Indonesia became governors there. Other advantages of amnesty are to avoid the threat of facing punishment (including death), thus decreasing the risks of surrender. An example is the Khmer Rouge rebellion in Cambodia. The conflict ended after its leaders had received 'pardons and security guarantees' (Peou, 2002: 524), i.e. the costs of surrender were reduced. The amnesty was instrumental in convincing Ieng Sary to end conflict, and he defected to the government in 1996 bringing some 3,000 fighters with him. He was pardoned by King Norodom Sihanouk and went on set up a political party that ruled a gem-rich western province that had been a Khmer Rouge stronghold.

From the democratization literature, we know that the threat of prosecutions of the outgoing regime may deter repressive regimes from relinquishing power (Sutter 1995), i.e. when the costs of surrender are increased. Escribà-Folch and Wright (2015: 346) examine how leaders' 'expectations about the ex post consequences of leaving power' affect the leader's decision to step down, and find that the threat of accountability makes the cost of leaving power higher for leaders, and so makes transition less likely. The proponents of amnesty argue that trials or the threat of trials can damage a peace process by dissuading the elites from ending their rule or entering negotiations and thus that amnesties can have an essential role to play in the interest of immediate transition or peace (Huntington 1991; Putnam 2002; Snyder and Vinjamuri 2003).

My expectation is that amnesty should increase the likelihood of negotiated settlements. Firstly, fighting will end in a negotiated settlement rather than government victory because the government has already recognised it cannot win a victory and thus has to offer concessions. If the government thinks it can win, it will not offer concessions, i.e. amnesty. The government uses amnesty as a non-military way to break the deadlock. Secondly, amnesty makes the payoffs from peace more attractive to the rebels. The two sides therefore move closer to an agreed settlement point and the conflict ends with concessions, i.e. in a negotiated settlement. I thus add to previous research by testing effects on the theoretically expected conflict ending - negotiated settlement. These considerations lead to the first hypothesis:

Hypothesis 1: During-conflict amnesty makes negotiated settlement more likely. 


\section{Amnesty as incentive}

An underpinning point is that governments wish to give the minimum amnesty necessary, since the use of amnesty can be criticized, for example, by opposition parties to say that the government is weak. Therefore, the government 1) gives the lowest level of amnesty possible, and 2) does not give amnesty at random, since there is a cost to pay, but only when it thinks that the amnesty will have a positive effect for the government. We can use this baseline assumption to examine disaggregated amnesties and test whether different amnesties have different effects. The first disaggregation is by the content of the amnesty. We can expect that if the government wants to give a stronger incentive, one option is to give a more generous amnesty. I consider amnesties that grant exemption from prosecution for even the most heinous crimes, particularly the international crimes of genocide, war crimes, or crimes against humanity as more generous. ${ }^{2} 30.5 \%$ of amnesties given during conflict can be identified as amnesties for heinous crimes. ${ }^{3}$ Such amnesties reduce the cost of surrender, since they amnesty a wider range of crimes and particularly those that often provoke the greatest calls domestically and internationally for action. Furthermore, accountability is more severe for these crimes than for other crimes and the fear of international justice higher. These effects are particularly pertinent for rebel leaders, since they are the ones who are attributed with responsibility for heinous acts. Freedom from prosecution for such crimes allows access to the benefits such as political positions that increase the value of the pact.

There is a widespread assumption in the literature and among practicioners that peace can be bought with amnesty, particularly amnesties for heinous crimes to culpable leaders (Snyder and Vinjamuri 2003; Scharf 1996; Roht-Arriaza 1990; Anonymous 1996). Such amnesties inspire much of the condemnation around amnesties. Given the widespread controversy that amnesties generate, it is important to test in a finer way whether such amnesties do indeed act as an incentive.

\section{Hypothesis 2: During-conflict amnesty for heinous crimes makes negotiated settlement more likely, whereas amnesties that exempt heinous crimes do not.}

\section{Amnesty as bargaining}

An alternative view to amnesty as an incentive, explored above, comes from bargaining theory, which identifies two main stumbling blocks to settlement (Fearon 1995, 2013; Powell 2002). The first is information asymmetries, whereby government and rebels misunderstand the capacities or resolve of the other side. The other stumbling block is the commitment problem, whereby civil wars last longer because the rebel group cannot trust the government not to renege on its promises in the future (Walter 2002; Kirschner 2010; Fearon 1995, 2004, 2013).

However, again we should not treat all amnesties as the same. Disaggregation of amnesties can allow us to examine whether amnesties are used to reduce information asymmetries and commitment problems. Amnesties can be given as formal or informal

\footnotetext{
2 These are serious violation (SV) amnesties in Dancy (2018).

${ }^{3}$ Author's data.
} 
offers. Formal amnesties are those passed as a law or decree. They are usually numbered and catalogued in the government register of laws or decrees and have a written text. By contrast, informal offers are, for example, offered in radio announcements or in a televised speech by the president. Such offers are reported in the news, but are not formally recorded. Giving a formal amnesty can be a strong declaration of the government's intentions, which helps reduce information asymmetries. A formal amnesty is a costly signal because it creates a written verifiable record of the amnesty. By contrast, an informal amnesty can be subsequently dismissed as mere words.

Formal amnesties can also reduce the commitment problem. The commitment problem states that rebels cannot trust the government not to renege on its promises after the end of conflict and particularly after the rebels have disarmed and so are vulnerable to a return to violence. The government can reduce the rebels' fear of being suckered in the future by tying themselves to a more formal declaration or one that involves more parties. The same argument is made with respect to peace agreements (Fortna 2004; Walter 2002; Hartzell and Hoddie 2003) and to signing up to international treaties (Simmons and Danner 2010). The argument that involving more actors serves to futureproof agreements underpins theories of the importance of international involvement in peace settlements (Doyle and Sambanis 2006; Fortna 2008; Hultman, Kathman, and Shannon 2014). In the same way, offering a formal amnesty law or decree helps to futureproof the decision as it is a formal way of proceeding that is preserved as a lasting record. Futhermore, passing an amnesty law may involve the consent of a broader constituency, such as the legislative body, including the opposition. Disaggregating amnesties into formal or informal offers allows us test whether amnesties are used to reduce information asymmetries and the commitment problem. I therefore present the following hypothesis:

\section{Hypothesis 3: During-conflict amnesties given as a formal offer make negotiated settlement more likely, whereas those given as informal offers do not.}

A contrasting position is that of Dancy (2018), who argues that the information transmitted by an amnesty is lost because adversaries will not trust the signal sent by the other side. From the rebels' point of view, an amnesty is either a trick or an expression that the government is weak and therefore the rebels are encouraged to fight on. If this is the case, we can expect amnesties to galvanize rebel fighters, inspiring them that the government is weak and victory is possible. All else equal, the effect of amnesties is to make rebel victories more likely. We can generate the following hypothesis:

Hypothesis 4: During-conflict amnesty makes rebel victory more likely.

\section{Indirect effects of amnesty}

The government can also use amnesty as a strategic tool to weaken the opposition. The direct effects of the amnesty are on the group (or faction) that settles with the government. This group has an "early leaver's" advantage, in that it can settle with concessions (Cunningham 
2011). One indirect effect of this amnesty can be that a rebel group has been removed from a multi-group conflict and there are fewer remaining groups. Nilsson (2010) studies the dynamics of multiple groups in a conflict and finds that costs are high for the group that is left isolated and still fighting. We saw this dynamic in the example of Algeria. With AIS out of the scene, the government was able to focus its efforts on defeating the GIA and through infiltration and military defeats it managed to effectively wipe out the GIA by 2002.

Another effect of the amnesty can be that a previously-unified rebel group fractures, with a faction accepting the amnesty. We see this tactic in the conflict in Chad in 2002. An amnesty in January to the MDJT (Mouvement pour la Démocratie et la Justice au Tchad) split the group into those who accepted the amnesty and a hard-line faction that continued fighting. Thus, the previously-unified rebel group is weakened (Cunningham 2011). Findlay and Rudloff (2012) find that rebel fragmentation increases the likelihood of shorter wars, since the resulting groups may not be so committed to conflict.

A third way in which the amnesty can give the government an advantage is by leapfrogging the leadership and enticing foot soldiers to leave. An example is the case of Cambodia. In 1994, the Khmer Rouge numbered around 15,000. In July, the government granted an amnesty to guerrillas who wished to desert from the Khmer Rouge, giving them six months to abandon violence and take up an incentive package of land and financial assistance along with freedom from prosecution. Thousands took up the offer and the fighting force reduced to 9,000 by the end of 1994 and 7,500 by the end of 1995. In 1996, the government offered a further amnesty. Ieng Sary, the Khmer Rouge second in command, took up this amnesty and fighting ended (Peou 2002).

Whether a group has left a multi-group conflict or a faction has left a previouslyunified rebel group, the government has weaker opponents, as they are fewer or more fragmented. The government can concentrate its firepower and forces on fewer groups or a smaller group, which gives rise to more success for the government. Groups in multi-group conflict have an incentive to be be first to settle, since the groups that are left fighting suffer higher costs (Nilsson 2010). The government, thus, has an incentive to give amnesties in multi-group conflict, in order to "divide and conquer" (Cunningham 2011). The argument is that the amnesty has a direct effect on the group that accepts it. It also has an indirect effect on the remaining fighters, since it means that the government is able to concentrate its forces on the remaining fighters. I thus propose the following hypothesis:

\section{Hypothesis 5: In a multi-group conflict, previous amnesty to other groups makes government victory or going to a low level of conflict more likely.}

\section{Research design}

The empirical analysis is carried out on the UCDP government-rebel group dyadic dataset, covering the years from 1975 to 2011 (Harbom, Melander, and Wallensteen 2008; Themner and Wallensteen 2012). I choose dyadic analysis because it allows a focus on the characteristics of specific opposition groups and finer tracking of the dynamics internal to a 
conflict. In a multi-group conflict, amnesty may end the dyadic conflict with smaller groups, yet have no effect on the dynamic of the bigger conflict and so the effects would not be seen in an analysis at conflict level. There are 374 dyadic conflicts within 148 conflicts.

I begin my analysis in 1975 because, prior to this date, human rights actions were solely concerned with the state as the responsible actor (Sikkink 2012). For example, in the Universal Declaration of Human Rights of 1948, the state as a whole is responsible for protecting the human rights of its citizens and is culpable if these are infringed, even though the rights may be violated by individual state representatives. A key step in switching the focus to individual criminal accountability was the adoption of the 1975 UN "Torture Declaration", ${ }^{4}$ along with domestic trials against individual military officers in Greece in 1975. From 1975 onwards, amnesty has a different meaning, which directly affects an individual's decision calculus.

The dependent variable is different conflict outcomes - negotiated settlement, rebel victory, government victory or going to a low level of conflict intensity, compared to continued fighting. The coding is taken from the 2015 version of the UCDP dyadic conflict termination dataset (Kreutz 2010). There are 130 negotiated settlements, 33 rebel victories, 68 government victories and 205 conflict reductions out of 436 conflict endings.

Amnesty

The independent variable of interest is the granting of an amnesty by the government. There are a number of datasets that compile information on transitional justice measures, but with different degrees of detail, making analysis difficult (DeMeritt 2016). The database used here is built primarily from Mallinder's Amnesty Law Database (Mallinder 2008) and the DuringConflict Justice dataset (Loyle and Binningsbø 2018). ${ }^{5}$ During-conflict amnesties have been largely ignored in research to date, even though they constitute 60\% of amnesties (Dancy 2018: 394). ${ }^{6}$ To comply with my theoretical interest, I do not include self-amnesties where governments give amnesties only to state forces, e.g. for state violence, and I include amnesties to active fighters so not pardons to prisoners or release of political prisoners. Each amnesty is matched to the specific side B to which it applies. For example, in Chad in 1992, there was an amnesty for only CSNPD, even though other groups were fighting at that time CNR, FNT, MDD. The independent variable for the analysis is coded as a dichotomous variable that takes the value of 1 if an amnesty is enacted during that calendar year (but prior to the conflict ending) or in the previous year. I am careful to exclude amnesties given or offered in the peace agreement that ends the conflict, to avoid equating the independent variable with the dependent variable. It is likely that during a period of settlement rebels are forward-thinking about their total package of gains and take into account their predictions of an action's consequences (Nilsson 2008; Walter 2006). Therefore, the anticipation of an

\footnotetext{
${ }^{4}$ In full, the Declaration on the Protection of All Persons from Being Subjected to Torture and Other Cruel, Inhuman or Degrading Treatment or Punishment, G.A. res. 3452 (XXX), annex, 30 U.N. GAOR Supp. (No. 34) at 91, U.N. Doc. A/10034 (1975), https://www1.umn.edu/humanrts/instree/h1dpast.htm [accessed 14 November 2015]

${ }^{5}$ I also cross-checked other datases of amnesties - the Transitional Justice Database (Payne, Olsen, and Reiter 2011), the Post-Conflict Justice datasets (Binningsbø et al. 2012), the Transitional Justice Research Collaborative (Dancy et al. 2014) - and primary sources - peace agreements (United Nations n.d.), Kessing News Archive and Factiva - to ensure a comprehensive dataset.

6 Though see Dancy (2018) and Loyle and Binningsbø (2018) for early work.
} 
amnesty in the settlement can be expected to influence the likelihood of a settlement. However, as stated above, including amnesties given in peace agreements would equate the independent and dependent variable. I therefore take a conservative coding. Applying these restrictions, there are 269 dyadic amnesties given to 130 dyads ( $34.7 \%$ of the total dyads).

I code for various disaggregations of amnesty. To test amnesty as an incentive, I examine amnesties that can be considered to be more generous. Some amnesties grant exemption from prosecution for even the most heinous crimes, particularly the international crimes of genocide, war crimes, or crimes against humanity. Firstly, the conflict must be one in which heinous crimes could have been committed. To code this, I rely on the information about one-sided violence from the UCDP database and the context of the conflict (Eck and Hultman 2007). I then examine the text of the amnesty, where available, or the reported description of the amnesty. On the one hand, there are 39 amnesties in the database that explicitly state that heinous crimes will not be covered by the amnesty. On the other hand, very few state explicitly that heinous crimes are included in the amnesty (though 16 amnesties do). Most amnesties that intend to exempt heinous crimes do so implicitly. I code as implicitly permitting heinous crimes where the text on the content of the amnesty includes words such as 'general amnesty' or 'amnesty to all', however, I take a conservative coding and code when these clearly include the crimes covered and not solely the recipient. The variable is a categorical variable where the base category is no amnesty, 1 signifies amnesty for heinous crimes and 2 signifies the amnesty does not cover heinous crimes. Applying these restrictions, I have 98 amnesties for heinous crimes.

I code a further disaggregation of amnesty in order to test amnesty as bargaining by measuring how the amnesty is granted. One method can be as laws and formal declarations. These include amnesties that are passed by the legislative body of the country and numbered decrees made by the leader. Usually these amnesties have a written text, are numbered and catalogued in the government register of laws or decrees. By contrast, informal offers are amnesties that are offered in a speech, for example on the radio or television, or amnesties offered in publicity campaigns. Such offers are reported in the news, but are not formally recorded. 140 amnesties are formal while 129 are informal offers.

In the analysis of amnesty as a means to military advantage, I hypothesize that the amnesty has the indirect effect of increasing the government's advantage because it removes some groups or fighters from the conflict and allows the government to focus its military efforts on fewer groups or more fragmented groups. I take a dummy variable of whether there are amnesties to other government-rebel group dyads within the same conflict. I expect that any effects take time to impact and so I measure amnesties to other groups in the previous year and in the previous three years.

\section{Controls}

I control for the relative strength between the rebels and the government, which can affect the likelihood for a conflict to end and the bargaining strengths of the parties, with stronger rebels more likely to enter negotiations (Clayton 2013). I use data from Cunningham, Gleditsch \& Salehyan (2009), ${ }^{7}$ and measure on a five-point scale whether rebels are weaker or stronger than the government, where rebel strength increases as the number increases. I

\footnotetext{
${ }^{7}$ Version 3.4 from 21 November 2013.
} 
also include the control variables common in the civil war literature for explaining conflict termination. These include the length of time fighting has been going on and the level of intensity measured by low battle deaths (up to 1,000 deaths) and high battle deaths (over 1,000 deaths). These are taken from the UCDP dataset. I also include incompatibility (taken from the UCDP dataset), since conflicts over territory tend to be longer (Fearon 2004). The presence of resources in the conflict area can also motivate rebels through 'greed' to capture wealth and can sustain rebels economically (Collier and Hoeffler 2004; Collier, Hoeffler, and Söderbom 2004). Resources are taken as the presence of gems, drug production or hydrocarbon production in the conflict area. These data are taken from Lujala (2010) and updated to 2011. The robust link between poverty and civil war is theorized to affect civil war termination by making a rebel 'career' an attractive financial option or through reducing the opportunity costs of recruitment (Collier \& Hoeffler, 2004; Collier, Hoeffler \& Soderbom, 2004). I use logged and lagged GDP per capita taken from Maddison (MaddisonProject 2013). I include lagged regime taken from the V-Dem project (Coppedge, Gerring, and Lindberg 2017) to ensure that the measure for formal amnesties does not simply capture a more legalistic state. Finally, I include a dummy variable for post-Cold War that marks the years post-1990 (Kalyvas and Balcells 2010) to control for the changes in the international system and forms of peace resolution (Doyle and Sambanis 2006; Walter 2002). Due to missing information in some of these variables, particularly the variable for GDP, the tests on different conflict endings have up to 1,511 observations, depending on the model.

I use a competing risks model to analyse the likelihood of negotiated settlement, rebel victory, government victory or conflict reduction versus continued conflict and use a multiple logit regression to create multiple competing outcomes. I account for duration dependence, thus treating the analysis as a survival analysis. Survival analysis allows me to deal with the right censoring of many of my cases (i.e. the conflict has not ended). I analyse how certain conditions, specifically the granting of an amnesty, increase the probability of the outcome. I time-set the data and create cubic functions to account for time dependence (Carter and Signorino 2010). I cluster errors on government-rebel group dyad in all models.

\section{Results}

Results for the analysis are shown in Table I, which presents the four separate outcomes (negotiated settlement, rebel victory, government victory and going to low level). The reference category is continued fighting. I discuss the results by the outcomes.

Table I. Effect of amnesties on different modes of conflict termination

\begin{tabular}{llllll}
\hline & $\begin{array}{l}\text { Model 1 } \\
\mathrm{b} / \mathrm{se}\end{array}$ & $\begin{array}{l}\text { Model 2 } \\
\mathrm{b} / \mathrm{se}\end{array}$ & $\begin{array}{l}\text { Model 3 } \\
\mathrm{b} / \mathrm{se}\end{array}$ & $\begin{array}{l}\text { Model 4 } \\
\mathrm{b} / \mathrm{se}\end{array}$ & $\begin{array}{l}\text { Model 5 } \\
\mathrm{b} / \mathrm{se}\end{array}$ \\
\hline Negotiated settlement & & & & & \\
Amnesty & & & & -0.103 & -0.100 \\
& -0.117 & & & $(0.49)$ & $(0.50)$ \\
\hline
\end{tabular}




\begin{tabular}{|c|c|c|c|c|c|}
\hline \multicolumn{2}{|l|}{$\begin{array}{l}\text { Amnesty for heinous } \\
\text { crime }\end{array}$} & $\begin{array}{l}-0.391 \\
(0.38)\end{array}$ & & & \\
\hline $\begin{array}{l}\text { Amnesty non-heinous } \\
\text { crime }\end{array}$ & & $\begin{array}{l}-0.090 \\
(0.55)\end{array}$ & & & \\
\hline Formal amnesty & & & $\begin{array}{l}0.672 * * * \\
(0.26)\end{array}$ & & \\
\hline Informal amnesty & & & $\begin{array}{l}-0.420 \\
(0.43)\end{array}$ & & \\
\hline $\begin{array}{l}\text { Amnesty to other groups, } \\
\text { previous year }\end{array}$ & & & & $\begin{array}{l}-1.164 * \\
(0.64)\end{array}$ & \\
\hline $\begin{array}{l}\text { Amnesty to other groups, } \\
\text { previous } 3 \text { years }\end{array}$ & & & & & $\begin{array}{l}-1.276^{* *} \\
(0.59)\end{array}$ \\
\hline Rebel strength & $\begin{array}{l}0.707 * * * \\
(0.16)\end{array}$ & $\begin{array}{l}0.692 * * * \\
(0.16)\end{array}$ & $\begin{array}{l}0.709^{* * *} \\
(0.16)\end{array}$ & $\begin{array}{l}1.211 * * * \\
(0.28)\end{array}$ & $\begin{array}{l}1.152^{* * * *} \\
(0.29)\end{array}$ \\
\hline Incompatibility territory & $\begin{array}{l}0.313 \\
(0.27)\end{array}$ & $\begin{array}{l}0.287 \\
(0.28)\end{array}$ & $\begin{array}{l}0.418 \\
(0.26)\end{array}$ & $\begin{array}{l}0.467 \\
(0.55)\end{array}$ & $\begin{array}{l}0.343 \\
(0.54)\end{array}$ \\
\hline Intensity & $\begin{array}{l}-0.613^{*} \\
(0.31)\end{array}$ & $\begin{array}{l}-0.585^{*} \\
(0.33)\end{array}$ & $\begin{array}{l}-0.588^{*} \\
(0.31)\end{array}$ & $\begin{array}{l}-1.325^{*} \\
(0.69)\end{array}$ & $\begin{array}{l}-1.301^{*} \\
(0.69)\end{array}$ \\
\hline Resources & $\begin{array}{l}-0.194 \\
(0.21)\end{array}$ & $\begin{array}{l}-0.209 \\
(0.22)\end{array}$ & $\begin{array}{l}-0.227 \\
(0.22)\end{array}$ & $\begin{array}{l}-0.058 \\
(0.52)\end{array}$ & $\begin{array}{l}-0.065 \\
(0.50)\end{array}$ \\
\hline Democracy lag & $\begin{array}{l}0.921 \\
(0.58)\end{array}$ & $\begin{array}{l}0.979 * \\
(0.58)\end{array}$ & $\begin{array}{l}0.944 \\
(0.58)\end{array}$ & $\begin{array}{l}-1.670 \\
(1.45)\end{array}$ & $\begin{array}{l}-1.093 \\
(1.41)\end{array}$ \\
\hline GDPpc log lag & $\begin{array}{l}-0.303 * * \\
(0.14)\end{array}$ & $\begin{array}{l}-0.293^{* *} \\
(0.15)\end{array}$ & $\begin{array}{l}-0.301 * * \\
(0.14)\end{array}$ & $\begin{array}{l}-0.004 \\
(0.31)\end{array}$ & $\begin{array}{l}-0.085 \\
(0.29)\end{array}$ \\
\hline Post-Cold War & $\begin{array}{l}1.333 * * * \\
(0.30)\end{array}$ & $\begin{array}{l}1.279 * * * \\
(0.30)\end{array}$ & $\begin{array}{l}1.321^{* * *} \\
(0.30)\end{array}$ & $\begin{array}{l}1.653 * * * \\
(0.53)\end{array}$ & $\begin{array}{l}1.590^{* * * *} \\
(0.51)\end{array}$ \\
\hline Number of dyads & & & & $\begin{array}{l}0.060 \\
(0.16)\end{array}$ & $\begin{array}{l}0.071 \\
(0.16)\end{array}$ \\
\hline Duration & $\begin{array}{l}-0.288^{* *} \\
(0.13)\end{array}$ & $\begin{array}{l}-0.285^{* *} \\
(0.14)\end{array}$ & $\begin{array}{l}-0.300^{* *} \\
(0.13)\end{array}$ & $\begin{array}{l}-0.506 \\
(0.32)\end{array}$ & $\begin{array}{l}-0.461 \\
(0.30)\end{array}$ \\
\hline Duration squared & $\begin{array}{l}0.026 * * \\
(0.01)\end{array}$ & $\begin{array}{l}0.027 * \\
(0.01)\end{array}$ & $\begin{array}{l}0.028^{* *} \\
(0.01)\end{array}$ & $\begin{array}{l}0.044 \\
(0.03)\end{array}$ & $\begin{array}{l}0.039 \\
(0.03)\end{array}$ \\
\hline Duration cubed & $\begin{array}{l}-0.001 * * \\
(0.00)\end{array}$ & $\begin{array}{l}-0.001 * \\
(0.00)\end{array}$ & $\begin{array}{l}-0.001 * * \\
(0.00)\end{array}$ & $\begin{array}{l}-0.001 \\
(0.00)\end{array}$ & $\begin{array}{l}-0.001 \\
(0.00)\end{array}$ \\
\hline Constant & $\begin{array}{l}-1.217 \\
(1.11)\end{array}$ & $\begin{array}{l}-1.284 \\
(1.16)\end{array}$ & $\begin{array}{l}-1.358 \\
(1.10)\end{array}$ & $\begin{array}{l}-2.393 \\
(2.91)\end{array}$ & $\begin{array}{l}-1.801 \\
(2.73)\end{array}$ \\
\hline \multicolumn{6}{|l|}{$\underline{\text { Rebel victory }}$} \\
\hline Amnesty & $\begin{array}{l}-0.680 \\
(0.61)\end{array}$ & & & & \\
\hline $\begin{array}{l}\text { Amnesty for heinous } \\
\text { crime }\end{array}$ & & $\begin{array}{l}-1.003 \\
(1.09)\end{array}$ & & & \\
\hline $\begin{array}{l}\text { Amnesty non-heinous } \\
\text { crime }\end{array}$ & & N/A & & & \\
\hline Formal amnesty & & & $\begin{array}{l}-0.575 \\
(0.81)\end{array}$ & & \\
\hline
\end{tabular}




\begin{tabular}{|c|c|c|c|c|c|}
\hline \multicolumn{3}{|l|}{ Informal amnesty } & \multicolumn{3}{|l|}{$\begin{array}{l}-1.141 \\
(0.87)\end{array}$} \\
\hline Rebel strength & $\begin{array}{l}1.153 * * * \\
(0.32)\end{array}$ & $\begin{array}{l}1.032 * * * \\
(0.35)\end{array}$ & $\begin{array}{l}1.160 * * * \\
(0.33)\end{array}$ & & \\
\hline Incompatibility territory & $\begin{array}{l}-0.614 \\
(0.91)\end{array}$ & $\begin{array}{l}-0.528 \\
(0.91)\end{array}$ & $\begin{array}{l}-0.619 \\
(0.91)\end{array}$ & & \\
\hline Intensity & $\begin{array}{l}0.653 \\
(0.51)\end{array}$ & $\begin{array}{l}0.735 \\
(0.51)\end{array}$ & $\begin{array}{l}0.659 \\
(0.50)\end{array}$ & & \\
\hline Resources & $\begin{array}{l}-0.568 \\
(0.49)\end{array}$ & $\begin{array}{l}-0.842 * \\
(0.46)\end{array}$ & $\begin{array}{l}-0.562 \\
(0.48)\end{array}$ & & \\
\hline Democracy lag & $\begin{array}{l}-1.289 \\
(1.77)\end{array}$ & $\begin{array}{l}-1.509 \\
(1.89)\end{array}$ & $\begin{array}{l}-1.238 \\
(1.77)\end{array}$ & & \\
\hline GDPpc log lag & $\begin{array}{l}-0.582 \\
(0.44)\end{array}$ & $\begin{array}{l}-0.794^{*} \\
(0.44)\end{array}$ & $\begin{array}{l}-0.594 \\
(0.44)\end{array}$ & & \\
\hline Post-Cold War & $\begin{array}{l}0.881^{*} \\
(0.51)\end{array}$ & $\begin{array}{l}0.767 \\
(0.49)\end{array}$ & $\begin{array}{l}0.888^{*} \\
(0.51)\end{array}$ & & \\
\hline Duration & $\begin{array}{l}-0.538 \\
(0.40)\end{array}$ & $\begin{array}{l}-0.447 \\
(0.40)\end{array}$ & $\begin{array}{l}-0.532 \\
(0.41)\end{array}$ & & \\
\hline Duration squared & $\begin{array}{l}0.056 \\
(0.06)\end{array}$ & $\begin{array}{l}0.044 \\
(0.06)\end{array}$ & $\begin{array}{l}0.056 \\
(0.06)\end{array}$ & & \\
\hline Duration cubed & $\begin{array}{l}-0.002 \\
(0.00)\end{array}$ & $\begin{array}{l}-0.002 \\
(0.00)\end{array}$ & $\begin{array}{l}-0.002 \\
(0.00)\end{array}$ & & \\
\hline Constant & $\begin{array}{l}-1.475 \\
(3.36)\end{array}$ & $\begin{array}{l}0.245 \\
(3.18)\end{array}$ & $\begin{array}{l}-1.430 \\
(3.39)\end{array}$ & & \\
\hline Government victory & & & & & \\
\hline Amnesty & $\begin{array}{l}-0.329 \\
(0.46)\end{array}$ & & & $\begin{array}{l}0.649 \\
(1.66)\end{array}$ & $\begin{array}{l}0.249 \\
(1.50)\end{array}$ \\
\hline $\begin{array}{l}\text { Amnesty for heinous } \\
\text { crime }\end{array}$ & & $\begin{array}{l}0.027 \\
(0.61)\end{array}$ & & & \\
\hline $\begin{array}{l}\text { Amnesty non-heinous } \\
\text { crime }\end{array}$ & & $\begin{array}{l}0.648 \\
(0.66)\end{array}$ & & & \\
\hline Formal amnesty & & & $\begin{array}{l}-0.575 \\
(0.63)\end{array}$ & & \\
\hline Informal amnesty & & & $\begin{array}{l}-0.279 \\
(0.60)\end{array}$ & & \\
\hline $\begin{array}{l}\text { Amnesty to other groups, } \\
\text { previous year }\end{array}$ & & & & $\begin{array}{l}-0.825 \\
(1.88)\end{array}$ & \\
\hline $\begin{array}{l}\text { Amnesty to other groups, } \\
\text { previous } 3 \text { years }\end{array}$ & & & & & $\begin{array}{l}0.032 \\
(1.38)\end{array}$ \\
\hline Rebel strength & $\begin{array}{l}-0.112 \\
(0.28)\end{array}$ & $\begin{array}{l}-0.058 \\
(0.27)\end{array}$ & $\begin{array}{l}-0.119 \\
(0.28)\end{array}$ & $\begin{array}{l}-0.161 \\
(0.99)\end{array}$ & $\begin{array}{l}-0.099 \\
(0.98)\end{array}$ \\
\hline Incompatibility territory & $\begin{array}{l}0.026 \\
(0.40)\end{array}$ & $\begin{array}{l}0.083 \\
(0.40)\end{array}$ & $\begin{array}{l}-0.002 \\
(0.40)\end{array}$ & N/A & N/A \\
\hline Intensity & $\begin{array}{l}-0.577 \\
(0.50)\end{array}$ & $\begin{array}{l}-0.640 \\
(0.46)\end{array}$ & $\begin{array}{l}-0.556 \\
(0.50)\end{array}$ & $\begin{array}{l}-0.047 \\
(0.88)\end{array}$ & $\begin{array}{l}0.069 \\
(0.85)\end{array}$ \\
\hline Resources & $\begin{array}{l}-0.654^{*} \\
(0.35)\end{array}$ & $\begin{array}{l}-0.699^{*} \\
(0.36)\end{array}$ & $\begin{array}{l}-0.649^{*} \\
(0.35)\end{array}$ & $\begin{array}{l}0.700 \\
(1.80)\end{array}$ & $\begin{array}{l}0.617 \\
(1.90)\end{array}$ \\
\hline
\end{tabular}




\begin{tabular}{|c|c|c|c|c|c|}
\hline Democracy lag & $\begin{array}{l}-1.221 \\
(0.95)\end{array}$ & $\begin{array}{l}-1.272 \\
(0.97)\end{array}$ & $\begin{array}{l}-1.237 \\
(0.94)\end{array}$ & $\begin{array}{l}-4.387 * \\
(2.52)\end{array}$ & $\begin{array}{l}-4.315 \\
(2.70)\end{array}$ \\
\hline GDPpc log lag & $\begin{array}{l}0.119 \\
(0.22)\end{array}$ & $\begin{array}{l}0.142 \\
(0.22)\end{array}$ & $\begin{array}{l}0.117 \\
(0.22)\end{array}$ & $\begin{array}{l}0.425 \\
(0.93)\end{array}$ & $\begin{array}{l}0.448 \\
(1.00)\end{array}$ \\
\hline Post-Cold War & $\begin{array}{l}0.567 \\
(0.35)\end{array}$ & $\begin{array}{l}0.525 \\
(0.35)\end{array}$ & $\begin{array}{l}0.571 \\
(0.35)\end{array}$ & $\begin{array}{l}0.520 \\
(1.30)\end{array}$ & $\begin{array}{l}0.410 \\
(1.28)\end{array}$ \\
\hline Number of dyads & & & & $\begin{array}{l}-1.673 \\
(1.14)\end{array}$ & $\begin{array}{l}-1.677 \\
(1.26)\end{array}$ \\
\hline Duration & $\begin{array}{l}-0.965^{* * *} \\
(0.23)\end{array}$ & $\begin{array}{l}-1.006^{* * *} \\
(0.23)\end{array}$ & $\begin{array}{l}-0.957 * * * \\
(0.23)\end{array}$ & $\begin{array}{l}-7.248 \\
(4.65)\end{array}$ & $\begin{array}{l}-7.309 \\
(4.97)\end{array}$ \\
\hline Duration squared & $\begin{array}{l}0.067 * * * \\
(0.02)\end{array}$ & $\begin{array}{l}0.070 * * * \\
(0.02)\end{array}$ & $\begin{array}{l}0.066 * * * \\
(0.02)\end{array}$ & $\begin{array}{l}1.495 \\
(0.98)\end{array}$ & $\begin{array}{l}1.510 \\
(1.05)\end{array}$ \\
\hline Duration cubed & $\begin{array}{l}-0.001 * * * \\
(0.00)\end{array}$ & $\begin{array}{l}-0.001 * * * \\
(0.00)\end{array}$ & $\begin{array}{l}-0.001 * * * \\
(0.00)\end{array}$ & $\begin{array}{l}-0.092 \\
(0.06)\end{array}$ & $\begin{array}{l}-0.093 \\
(0.07)\end{array}$ \\
\hline Constant & $\begin{array}{l}-0.749 \\
(1.82)\end{array}$ & $\begin{array}{l}-0.865 \\
(1.85)\end{array}$ & $\begin{array}{l}-0.732 \\
(1.81)\end{array}$ & $\begin{array}{l}7.913 \\
(12.40)\end{array}$ & $\begin{array}{l}7.616 \\
(12.57)\end{array}$ \\
\hline Go to low level & & & & & \\
\hline Amnesty & $\begin{array}{l}-0.616^{* *} \\
(0.27)\end{array}$ & & & $\begin{array}{l}-1.216^{* *} \\
(0.56)\end{array}$ & $\begin{array}{l}-0.605 \\
(0.40)\end{array}$ \\
\hline $\begin{array}{l}\text { Amnesty for heinous } \\
\text { crime }\end{array}$ & & $\begin{array}{l}-0.873^{*} \\
(0.50)\end{array}$ & & & \\
\hline $\begin{array}{l}\text { Amnesty non-heinous } \\
\text { crime }\end{array}$ & & $\begin{array}{l}-1.045 \\
(0.64)\end{array}$ & & & \\
\hline Formal amnesty & & & $\begin{array}{l}-0.736^{* *} \\
(0.33)\end{array}$ & & \\
\hline Informal amnesty & & & $\begin{array}{l}-0.495 \\
(0.34)\end{array}$ & & \\
\hline $\begin{array}{l}\text { Amnesty to other groups, } \\
\text { previous year }\end{array}$ & & & & $\begin{array}{l}1.443 * * * \\
(0.49)\end{array}$ & \\
\hline $\begin{array}{l}\text { Amnesty to other groups, } \\
\text { previous } 3 \text { years }\end{array}$ & & & & & $\begin{array}{l}0.721^{* *} \\
(0.36)\end{array}$ \\
\hline Rebel strength & $\begin{array}{l}-0.777 * * * \\
(0.23)\end{array}$ & $\begin{array}{l}-0.775^{* * *} \\
(0.24)\end{array}$ & $\begin{array}{l}-0.772 * * * \\
(0.23)\end{array}$ & $\begin{array}{l}-0.716^{*} \\
(0.41)\end{array}$ & $\begin{array}{l}-0.709^{*} \\
(0.42)\end{array}$ \\
\hline Incompatibility territory & $\begin{array}{l}0.211 \\
(0.23)\end{array}$ & $\begin{array}{l}0.174 \\
(0.24)\end{array}$ & $\begin{array}{l}0.193 \\
(0.23)\end{array}$ & $\begin{array}{l}1.003^{* *} \\
(0.44)\end{array}$ & $\begin{array}{l}1.027 * * \\
(0.42)\end{array}$ \\
\hline Intensity & $\begin{array}{l}-1.865^{* * *} \\
(0.47)\end{array}$ & $\begin{array}{l}-1.804 * * * \\
(0.46)\end{array}$ & $\begin{array}{l}-1.871 * * * \\
(0.47)\end{array}$ & $\begin{array}{l}-1.996^{* *} \\
(0.83)\end{array}$ & $\begin{array}{l}-2.089 * * \\
(0.84)\end{array}$ \\
\hline Resources & $\begin{array}{l}-0.501 * * \\
(0.21)\end{array}$ & $\begin{array}{l}-0.454 * * \\
(0.22)\end{array}$ & $\begin{array}{l}-0.493^{* *} \\
(0.21)\end{array}$ & $\begin{array}{l}-1.240 * * * \\
(0.41)\end{array}$ & $\begin{array}{l}-1.206^{* * * *} \\
(0.41)\end{array}$ \\
\hline Democracy lag & $\begin{array}{l}-0.932^{*} \\
(0.55)\end{array}$ & $\begin{array}{l}-0.836 \\
(0.55)\end{array}$ & $\begin{array}{l}-0.912^{*} \\
(0.55)\end{array}$ & $\begin{array}{l}0.685 \\
(0.88)\end{array}$ & $\begin{array}{l}0.475 \\
(0.87)\end{array}$ \\
\hline GDPpc log lag & $\begin{array}{l}-0.154 \\
(0.13)\end{array}$ & $\begin{array}{l}-0.155 \\
(0.13)\end{array}$ & $\begin{array}{l}-0.154 \\
(0.13)\end{array}$ & $\begin{array}{l}-0.619^{* *} \\
(0.26)\end{array}$ & $\begin{array}{l}-0.571^{* *} \\
(0.26)\end{array}$ \\
\hline Post-Cold War & $\begin{array}{l}0.705 * * * \\
(0.24)\end{array}$ & $\begin{array}{l}0.671 * * * \\
(0.24)\end{array}$ & $\begin{array}{l}0.707 * * * \\
(0.24)\end{array}$ & $\begin{array}{l}0.014 \\
(0.45)\end{array}$ & $\begin{array}{l}0.033 \\
(0.47)\end{array}$ \\
\hline Number of dyads & & & & $\begin{array}{l}0.149 \\
(0.13)\end{array}$ & $\begin{array}{l}0.128 \\
(0.14)\end{array}$ \\
\hline
\end{tabular}




\begin{tabular}{llllll}
\hline Duration & $-0.302 * * *$ & $-0.270^{* *}$ & $-0.305^{* * *}$ & -0.294 & -0.355 \\
& $(0.11)$ & $(0.11)$ & $(0.11)$ & $(0.20)$ & $(0.22)$ \\
Duration squared & $0.032 * *$ & $0.028^{* *}$ & $0.032^{* *}$ & 0.025 & 0.031 \\
& $(0.01)$ & $(0.01)$ & $(0.01)$ & $(0.02)$ & $(0.02)$ \\
Duration cubed & $-0.001^{* *}$ & $-0.001^{* *}$ & $-0.001^{* *}$ & -0.001 & -0.001 \\
& $(0.00)$ & $(0.00)$ & $(0.00)$ & $(0.00)$ & $(0.00)$ \\
Constant & $3.122^{* * *}$ & $3.032^{* * *}$ & $3.136^{* * *}$ & $6.356 * *$ & $6.230^{* *}$ \\
& $(1.12)$ & $(1.13)$ & $(1.12)$ & $(2.59)$ & $(2.59)$ \\
& & & & & \\
\hline Observations & 1511 & 1426 & 1511 & 488 & 488 \\
Pseudologlikelihood & -999.075 & -958.219 & -993.598 & -264.769 & -264.172 \\
AIC & 2094.150 & 2020.437 & 2091.196 & 641.538 & 640.344 \\
BIC & 2349.536 & 2294.094 & 2367.863 & 876.196 & 875.002 \\
\hline
\end{tabular}

Significance: $* \mathrm{p}<0.1, * * \mathrm{p}<0.05, * * * \mathrm{p}<0.01$. Standard errors clustered on dyad reported in brackets. N/A: insufficient cases in the cell to compute reliable values ("Multinomial Logistic Regression: Stata Data Analysis Examples" n.d.).

\section{Negotiated settlement}

The first set of results examine the likelihood of the government-rebel group dyadic conflict ending in a negotiated settlement. The first hypothesis is that amnesty makes negotiated settlement more likely through the twin motivations of making the pact more valuable to rebels and reducing the cost of surrender. We see from the results in Model 1 that simply looking at aggregated amnesties does not show any significant results, meaning conflict is no more likely to end in a negotiated settlement than continued fighting. To get more leverage on amnesty as an incentive, Model 2 separates amnesties for heinous crimes from other amnesties. The second hypothesis states that amnesties for heinous crimes will be a stronger incentive because they go further in making the pact more attractive and in reducing the negative consequences of surrender. However, the results suggest that an amnesty for heinous crimes has no significant effect on a conflict ending sooner in a negotiated settlement. A possible interpretation is that leaders do not trust these amnesties to shield them from international justice and so we see no effects. We should expect that this fear has increased in recent years. Yet testing the results with an interaction between amnesty and post-2002, the year the Rome Statute establishing the ICC came into force, shows no difference in impact (Table A2 in the Appendix). The result is surprising and goes against many of the assumptions in the transitional justice literature. Yet it supports other findings that amnesties for the worst crimes are not more effective at ending conflict (Dancy 2018), and here we see that this finding also holds for negotiated settlement. However, the results should be treated with caution since these data are only for amnesties given prior to the conflict ending and so do not include those amnesties that rebels expect to receive in the peace agreement and so likely underestimate the effects of amnesty.

The next hypothesis examines amnesty within the bargaining model, with the argument that amnesty reveals information about the government's intentions and trustworthiness. Model 3 looks at amnesties disaggregated into formal and informal offers. A formal amnesty makes a conflict significantly more likely to end in negotiated settlement. The average predicted probabilities show that a formal amnesty makes conflict 6 percentage points more likely to end in a negotiated settlement. The results are shown in Figure 2. 


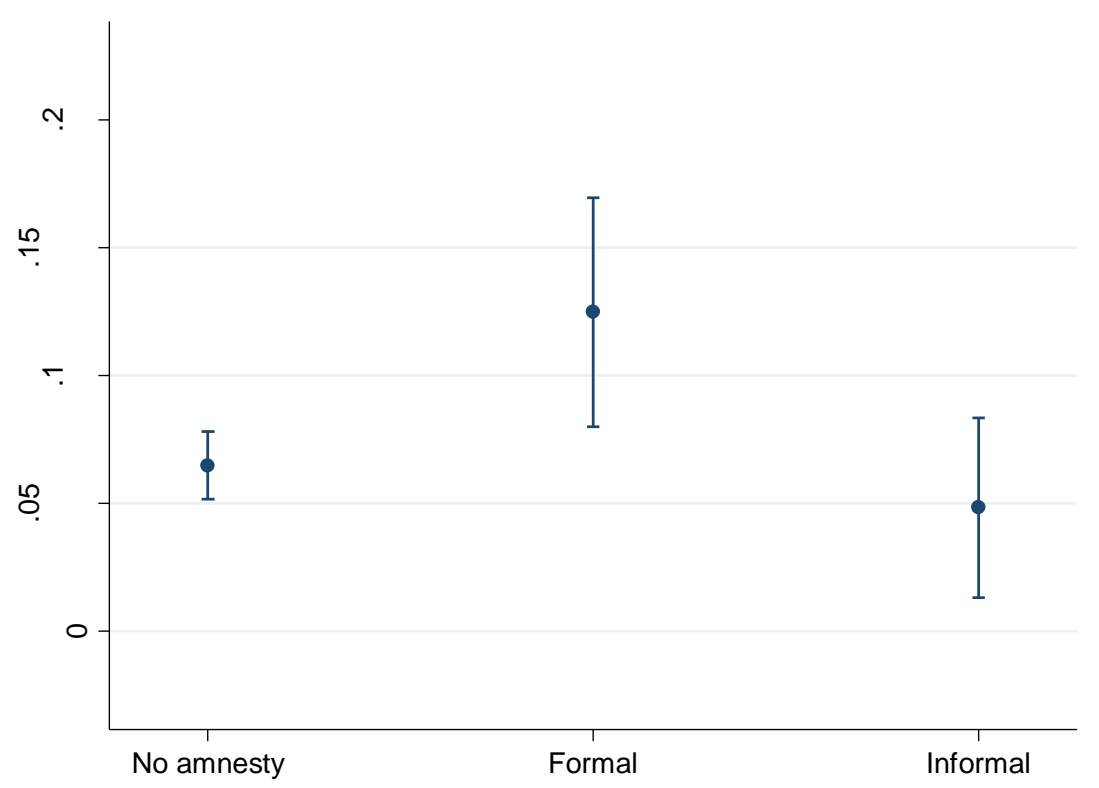

Figure 2: Average predicted probabilities of negotiated settlement by type of amnesty. Confidence intervals reported at $95 \%$. The graph shows that across all government-rebel group dyad years, those with a formal amnesty are significantly more likely to be followed by a negotiated settlement than no amnesty. On average, the increase is 6 percentage points more likely.

The results support the idea that the government can use amnesties as a non-military way to decrease the information asymmetries during conflict or as a way to somewhat mitigate the commitment problem. Obviously, amnesty cannot eliminate the commitment problem. Rebels fear being betrayed even with internationally-supervised signed peace agreements. However, a formal amnesty as compared with an informal amnesty can give some reassurance that the government is not suckering the rebels. Therefore, we see that amnesty has a significant effect on making negotiated settlement more likely.

Again, we should remember that these results do not include the amnesty given in the final settlement. We know that rebels are forward-thinking about their total package of gains (Nilsson 2008; Walter 2006) and we can expect the true impact of amnesty to be higher. However, given the methodological constraints of not equating the independent and dependent variable, the test shown here allows us to isolate some of that impact.

Across all the models for negotiated settlements, the control variables show that, as expected, stronger rebels lead to earlier negotiated settlements (Clayton 2013). Also in line with previous literature on mediation (Gartner and Bercovitch 2006; Bercovitch and DeRouen 2005; Clayton and Gleditsch 2014), high intensity conflicts are less likely to end in negotiated settlement. Poorer countries are more willing to settle, perhaps because the costs of conflict are more difficult to sustain (Mason, Weingarten Jnr, and Fett 1999) and negotiated settlements are more likely in the post-Cold War era (Balcells and Kalyvas 2014).

Rebel victory

Hypothesis 3 stated that amnesty increased the likelihood of rebel victory, because rebels interpret it as a sign of weakness on the part of the government and so are galvanised to fight 
for victory. The results for rebel victory are shown in the second part of the table. ${ }^{8}$ We find no support for the idea that amnesty increases the likelihood of rebel victory. I expect generous amnesties to encourage this kind of reaction, yet in Model 2 we also see no significant results. Likewise, I expect that informal amnesties can be interpreted as the government clutching at straws, but again, in Model 3, there are no significant results. Amnesty makes rebel victory no more likely than continued fighting. Granting amnesty does not make the rebels think the government is weak, even when the government gives more generous amnesties.

\section{Government advantage}

A different way to interpret amnesties is as a means for the government to accrue military advantage. An amnesty can remove groups from a conflict, as we saw in the example of Algeria. The government is then fighting on fewer fronts and can concentrate its forces on the remaining groups. Empirically, there seems to be support for this argument. If we look at the impact of amnesty on the mean of government victory and going to a low level of intensity in the three years before an amnesty and the three years after an amnesty, we see a noticeable increase in the mean of government victory and going to low level in the years after an amnesty (Figure 3).

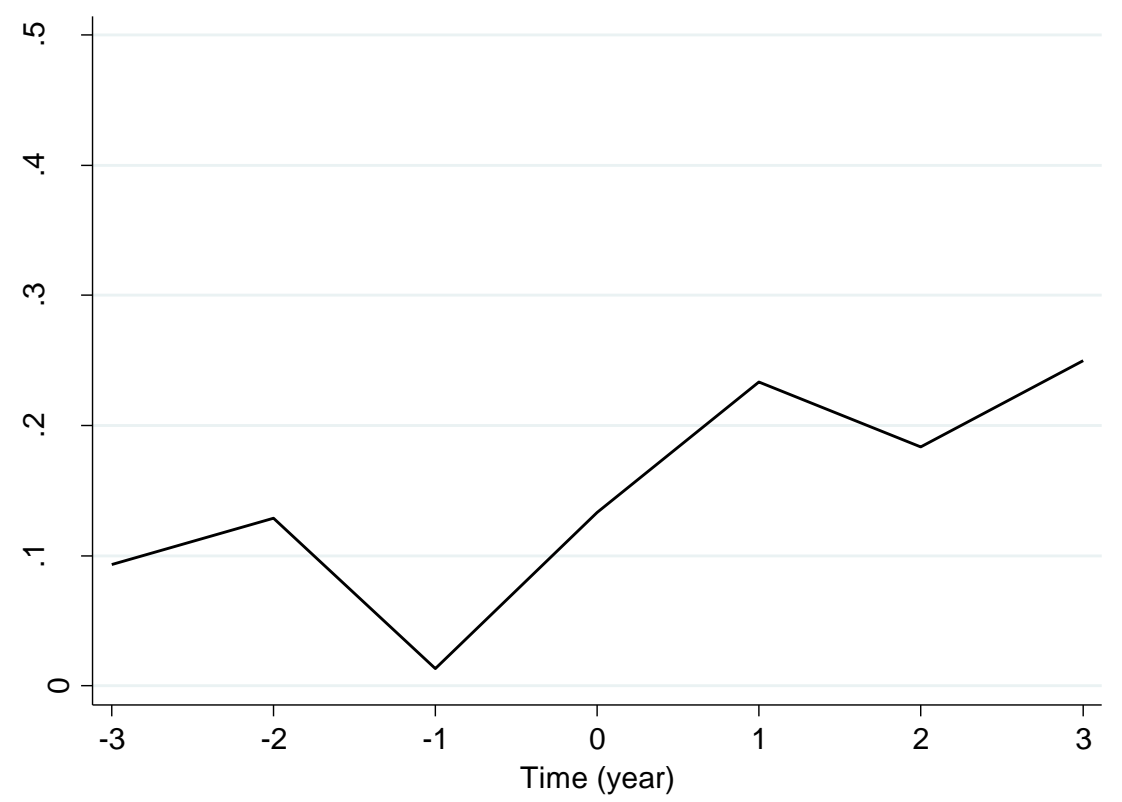

Figure 3: Mean of government victory and conflict reduction. The graph shows the mean of government victory and the conflict going to a low level of deaths in the 3 years prior to an amnesty and in the 3 years following an amnesty.

The proposed mechanism is that amnesty to other groups leads to government advantage over the group left fighting. Amnesty can serve to shut down or suck away followers from other rebel factions, thus allowing the government to concentrate its forces on the remaining

\footnotetext{
${ }^{8}$ Note that because of the low number of rebel victories, some of the results are not reliable ("Multinomial Logistic Regression: Stata Data Analysis Examples" n.d.). They have been omitted.
} 
groups. Such a dynamic would lead us to expect that a conflict with the group in question is more likely to end in government victory or going to a low level. The analysis is shown in Models 4 and 5, which include different lags for amnesty to other groups. The analysis is run on only those government-rebel group dyads that are in a conflict where more than one dyad is active. Hence, the number of observations is lower. The results support the hypotheses, though only for the lower hurdle of going to a low level and not for government victory. From the average marginal effects on Model 4 we see that amnesty to other groups in the previous year increases the likelihood of going to a low level of confict by 15.4 percentage points. The average adjusted predictions are shown in Figure 4. Testing this effect on amnesties given within the last three years (Model 5) shows that the effect continues across time, though with a diminishing effect, with conflict reduction more likely by 6.5 percentage points. These results support the argument that amnesty increases the government's military advantage, as we saw in the example of Algeria.

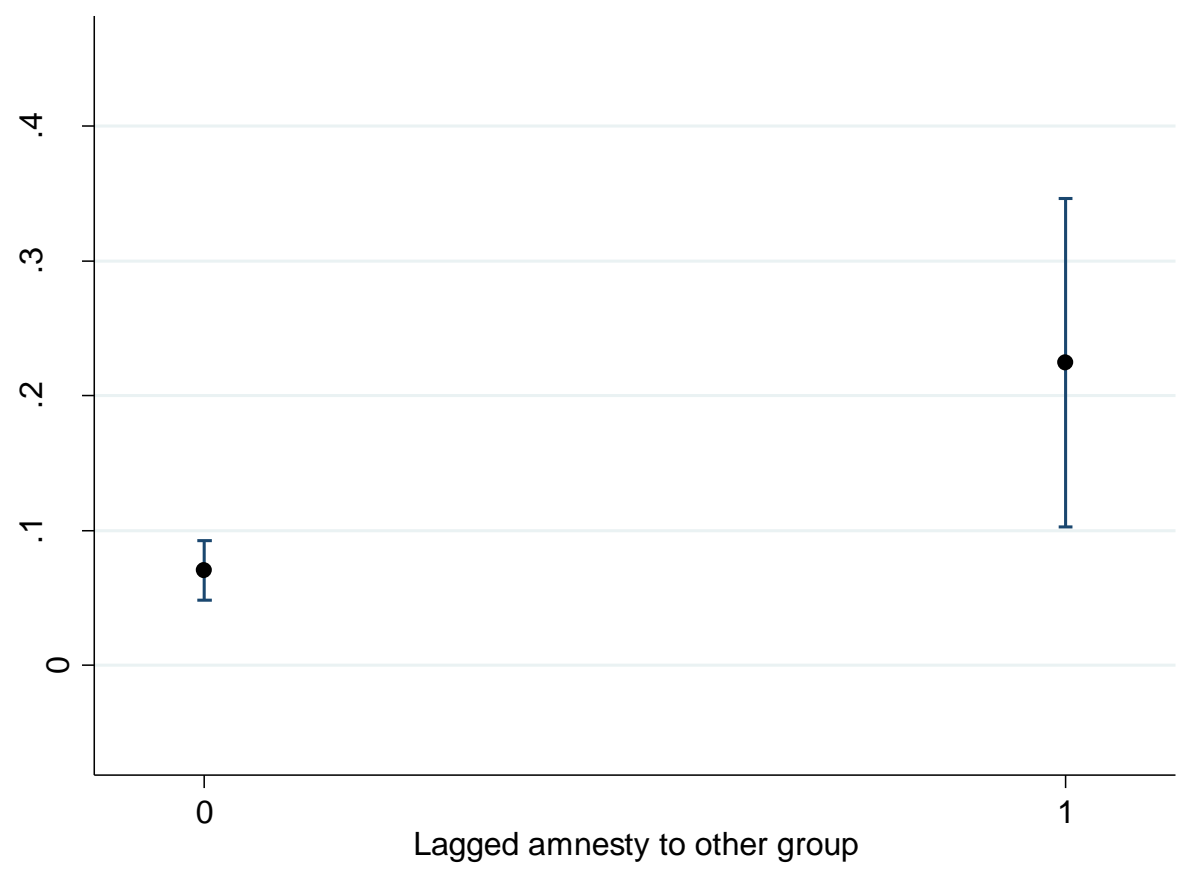

Figure 4: Average adjusted predictions of conflict going to low level. Confidence intervals reported at $95 \%$. The graph shows the statistically significant increased likelihood of conflict going to low level after an amnesty to another government-rebel group dyad within the same conflict.

Across the results for government victory and going to low level, the presence of resources makes conflict reduction less likely (Ross 2004). Resources enable the leadership to sustain the conflict and buy the loyalty of their troops. This result underscores the importance of tempting fighters away with an offer that can replace the benefits of resources. Testing the interplay of amnesties and reintegration packages would be a useful further research.

To further test the models in Table I, I add the following robustness checks. I explore whether having a third-party intervention acts as a security guarantee and so impacts on the effectiveness of an amnesty (Fearon 1995; Walter 1997). The argument is that the reputational cost of reneging on the amnesty law is higher. I measure third-party operation by 
the lagged presence of a UN Peace-Keeping Operation (PKO) in the country, taken from the International Peace Institute (Perry and Smith 2013), and the data date from 1990 (Table A3 in the Appendix). The results show formal amnesty still makes negotiated settlement more likely, though with a lower significance. The result raises the interesting suggestion that amnesty is primarily a domestic action that may compensate for lack of international oversight. This is a proposal that could be explored in future research. The second robustness check is to include a control for one-sided violence (Eck and Hultman 2007) with data available from 1989 (Table A4 in the Appendix). Note that war crimes are already taken into account in the coding of amnesties for heinous crimes so results for this model do not change. Formal amnesties retain their strong significance and have more impact. The marginal effects show an impact that negotiated settlement is 10.7 percentage points more likely after a formal amnesty compared to no amnesty. Both the data for Peace-Keeping Operations and one-sided violence reduce the number of observations as the data are only available from 1989 or 1990. As amnesties are already not numerous, I am conscious of the difficulties that come with reducing further the $\mathrm{N}$. In both cases, due to the data limitations, Models 4 and 5 do not solve. I also run tests where I remove outliers on the highest count of amnesties and duration of dyadic conflict - both the FARC in Colombia (Table A5 in the Appendix). Again, the results do not change.

\section{Conclusion}

The use of amnesty, particularly amnesties that allow perpetrators to escape prosecution for the most heinous crimes, have long provoked controversy. Many scholars argue that prosecution is essential, and international law and the UN seem to be following this point of view and turning against amnesties. Other scholars take a more realist stance and argue that amnesty, while undesirable, may prevent further bloodshed by helping end conflicts earlier. In the midst of this debate, we have little cross-national information on the effects of amnesty specifically in civil war. This article contributes to this debate and as such, it talks to an important and relevant topical debate.

Previous results find that amnesties do not make conflict end more quickly (Reiter 2014; Dancy 2018). However, prior research did not separate the diverse ways in which conflict can end. By aggregating all endings, we miss the different ways in which amnesty can have an effect. This article adds to the literature by developing theoretical explanations of the mechanisms by which amnesties can have an effect and then asking whether different amnesties have an impact on competing types of endings - negotiated settlement, rebel victory, government victory or going to a low level of conflict intensity.

The research here shows that amnesty given during conflict can work in different ways. One important finding is that amnesties for heinous crimes are not more effective than amnesties than exclude heinous crimes in reaching negotiated settlements. This finding is a boost to the international community that has mobilized against such amnesties, since they are shown to be ineffective in making negotiated settlement more likely. 
A second important finding is that amnesty has its strongest impact when it is trustworthy, i.e. a formal declaration. This result adds support to the many findings that commitment problems matter when ending conflicts. The result also supports those who argue that amnesty can play a positive role of building trust and bringing groups in from the cold (Mallinder and Hadden 2013; Freeman 2009). Amnesty can be part of the compromises that can help settle a conflict.

There is also some support for the argument that governments use amnesties to increase their military advantage. As we saw in the examples of Algeria and Chad, amnesty can be used to end the conflict with one group, leaving the government more able to focus their forces on the remaining group. This finding is a novel addition to the literature.

These results also have implications for policy on the use of amnesty. The findings support recent research that shows that giving generous amnesties during conflict is not of use in ending conflict sooner (Dancy 2018). However, amnesty can be an valuable nonmilitary way to make a negotiated settlement more likely. In particular, they are a domestic measure that can help address the commitment problem. The finding that formal amnesties are effective has important implications for negotiators. There is therefore a role for ethical amnesties in keeping with international law (Mallinder and Hadden 2013).

Data replication: The dataset, codebook and do files for the empirical analyses in this article can be found in the online Appendix. The analyses were conducted using stata 14 . 


\section{References}

Anonymous. 1996. "Human Rights in Peace Negotiations." Human Rights Quarterly 18 (2): 249-58.

Balcells, Laia, and Stathis N. Kalyvas. 2014. "Does Warfare Matter? Severity, Duration, and Outcomes of Civil Wars." Journal of Conflict Resolution 58 (8): 1390-1418.

Bercovitch, Jacob, and Karl DeRouen. 2005. "Managing Ethnic Civil Wars: Assessing the Determinants of Successful Mediation." Civil Wars 7 (1): 98-116.

Biddle, Stephen, Jeffrey A. Friedman, and Jacob N. Shapiro. 2012. "Testing the Surge: Why Did Violence Decline in Iraq in 2007?" International Security 37 (1): 7-40.

Binningsbø, Helga Malmin, Cyanne E Loyle, Scott Gates, and Jon Elster. 2012. "Armed Conflict and Post-Conflict Justice, 1946-2006: A Dataset." Journal of Peace Research 49 (5): 731-40.

Carter, David B., and Curtis S. Signorino. 2010. "Back to the Future: Modeling Time Dependence in Binary Data." Political Analysis 18 (3): 271-92.

Clayton, Govinda. 2013. "Relative Rebel Strength and the Onset and Outcome of Civil War Mediation." Journal of Peace Research 50 (5): 609-22.

Clayton, Govinda, and Kristian Skrede Gleditsch. 2014. "Will We See Helping Hands?

Predicting Civil War Mediation and Likely Success." Conflict Management and Peace Science 31 (3): 265-84.

Collier, Paul, and Anke Hoeffler. 2004. "Greed and Grievance in Civil War." Oxford Economic Papers 56 (4): 563-95.

Collier, Paul, Anke Hoeffler, and Måns Söderbom. 2004. "On the Duration of Civil War." Journal of Peace Research 41 (3): 253-73.

Coppedge, Micheal, John Gerring, and Staffan I. Lindberg. 2017. "V-Dem Dataset v7.1." Varieties of Democracy (V-Dem) Project.

Cunningham, Kathleen Gallagher. 2011. "Divide and Conquer Or Divide and Concede: How Do States Respond to Internally Divided Separatists." American Political Science Review 105 (2): 275-97.

Dancy, Geoff. 2018. "Deals with the Devil? Conflict Amnesties, Civil War, and Sustainable Peace." International Organization 72 (2): 387-421.

Dancy, Geoff, Francesca Lessa, Bridget Marchesi, Leigh A. Payne, Gabriel Pereira, and Kathryn Sikkink. 2014. "The Transitional Justice Research Collaborative: Bridging the Qualitative-Quantitative Divide With New Data.” 2014. www.transitionaljusticedata.com.

DeMeritt, Jacqueline H.R. 2016. "Transitional Justice: Prospects for Postwar Peace and Human Rights.” In What Do We Know about Civil Wars?, edited by T. David Mason and Sara McLaughlin Mitchell, 179-97. Lanham, MA: Rowman \& Littlefield.

Doyle, Michael W, and Nicholas Sambanis. 2006. Making War and Building Peace: United Nations Peace Operations. Princeton, NJ: Princeton University Press.

Eck, Kristine, and Lisa Hultman. 2007. "One-Sided Violence Against Civilians in War." Journal of Peace Research 44 (2): 233-46.

Escribà-Folch, Abel, and Joseph Wright. 2015. "Human Rights Prosecutions and Autocratic 
Survival." International Organization 69 (2): 343-73.

Fearon, James D. 1995. “Rationalist Explanations for War.” International Organization 49 (3): $379-414$.

—. 2004. "Why Do Some Civil Wars Last so Much Longer than Others?" Journal of Peace Research 41 (3): 275-301.

- 2013. "Fighting Rather than Bargaining." Stanford University.

Fearon, James D, and David D Laitin. 2003. "Ethnicity, Insurgency, and Civil War." American Political Science Review 97 (1): 75-90.

Findley, Michael, and Peter Rudloff. 2012. "Combatant Fragmentation and the Dynamics of Civil Wars." British Journal of Political Science 42 (4): 879-901.

Fortna, Virginia Page. 2004. Peace Time: Cease-Fire Agreements and the Durability of

Peace. Princeton, NJ: Princeton University Press.

- 2008. Does Peacekeeping Work? Shaping Belligerents' Choices after Civil War.

Princeton, NJ: Princeton University Press.

Freeman, Mark. 2009. Necessary Evils: Amnesties and the Search for Justice. Cambridge:

Cambridge University Press.

Gartner, Scott Sigmund, and Jacob Bercovitch. 2006. "Overcoming Obstacles to Peace: The Contribution of Mediation to Short-Lived Conflict Settlements." International Studies Quarterly 50 (4): 819-40.

Hagelstein, Roman. 2008. "Explaining the Violence Pattern of the Algerian Civil War." Households in Conflict Network Working Papers 43: 1-28.

Harbom, Lotta, Erik Melander, and Peter Wallensteen. 2008. "Dyadic Dimensions of Armed Conflict, 1946-2007." Journal of Peace Research 45 (5): 697-710.

Hartzell, Caroline A., and Matthew Hoddie. 2003. "Institutionalizing Peace: Power Sharing and Post-Civil War Conflict Management." American Journal of Political Science 47 (2): 318-32.

Hultman, Lisa, Jacob Kathman, and Megan Shannon. 2014. "Beyond Keeping Peace: United Nations Effectiveness in the Midst of Fighting.” American Political Science Review 108 (4): 737-53.

Human Rights Watch. 2001. "World Report 2001 - Algeria: Human Rights Developments." http://www.hrw.org/legacy/wr2k1/mideast/algeria.html [accessed 30 May 2017].

Huntington, Samuel P. 1991. The Third Wave: Democratization in the Late Twentieth Century. Norman: University of Oklahoma Press.

Johnston, Patrick B. 2012. "Does Decapitation Work? Assessing the Effectiveness of Leadership Targeting in Counterinsurgency Campaigns." International Security 36 (4): 47-79.

Kalyvas, Stathis N. 2006. The Logic of Violence in Civil War. Cambridge: Cambridge University Press.

Kalyvas, Stathis N., and Laia Balcells. 2010. "International System and Technologies of Rebellion: How the End of the Cold War Shaped Internal Conflict." American Political Science Review 104 (3): 415-29.

Kirschner, Shanna A. 2010. "Knowing Your Enemy: Information and Commitment Problems in Civil Wars." Journal of Conflict Resolution 54 (5): 745-70.

Kreutz, Joakim. 2010. "How and When Armed Conflicts End: Introducing the UCDP 
Conflict Termination Dataset." Journal of Peace Research 47 (2): 243-50.

Loyle, Cyanne E., and Helga Malmin Binningsbø. 2018. "Justice during Armed Conflict." Journal of Conflict Resolution 62 (2): 442-66.

Lujala, Paivi. 2010. "The Spoils of Nature: Armed Civil Conflict and Rebel Access to

Natural Resources." Journal of Peace Research 47 (1): 15-28.

Maddison-Project. 2013. "Maddison Project." 2013. http://www.ggdc.net/maddison.

Mallinder, Louise. 2008. Amnesty, Human Rights and Political Transitions: Bridging the

Peace and Justice Divide. Oxford: Hart Publishing.

_. 2009. "Global Comparison of Amnesty Laws." Siracusa: The International Institute of Higher Studies in Criminal Sciences. http://ssrn.com/abstract=1586831.

Mallinder, Louise, and Tom Hadden. 2013. The Belfast Guidelines on Amnesty and Accountability. Belfast: Transitional Justice Institute.

Mason, T David, and Patrick J Fett. 1996. "How Civil Wars End: A Rational Choice Approach." Journal of Conflict Resolution 40 (4): 546-68.

Mason, T David, Joseph P Weingarten Jnr, and Patrick J Fett. 1999. "Win, Lose or Draw: Predicting the Outcome of Civil Wars." Political Research Quarterly 52 (2): 239-68.

Melin, Molly M., and Isak Svensson. 2009. "Incentives for Talking: Accepting Mediation in International and Civil Wars." International Interactions 35 (3): 249-71.

Mendez, Juan. 2012. "Foreword." In Amnesty in the Age of Human Rights Accountability, edited by Francesca Lessa and Leigh A Payne, xvii-xxix. Cambridge: Cambridge University Press.

"Multinomial Logistic Regression: Stata Data Analysis Examples." n.d. UCLA: Statistical Consulting Group. Accessed November 11, 2019.

https://stats.idre.ucla.edu/stata/dae/multinomiallogistic-regression/.

Nilsson, Desiree. 2008. "Partial Peace: Rebel Groups inside and Outside of Civil War Settlements." Journal of Peace Research 45 (4): 479-95.

_. 2010. "Turning Weakness into Strength: Military Capabilities, Multiple Rebel Groups and Negotiated Settlements." Conflict Management and Peace Science 27 (3): 253-71.

Olsen, Tricia D, Leigh A Payne, and Andrew G Reiter. 2010. Transitional Justice in Balance: Comparing Processes, Weighing Efficacy. Washington, DC: United States Institute of Peace Press.

Orentlicher, Diane F. 1991. "Settling Accounts: The Duty to Prosecute Human Rights Violations of a Prior Regime." Yale Law Journal 100 (8): 2537-2615.

_ 1996. "Swapping Amnesty for Peace and the Duty to Prosecute Human Rights Crimes." ILSA Journal of International and Comparative Law 3: 713.

Patterson, Eric D. 2012. Ending Wars Well. New Haven, CT: Yale University Press. Payne, Leigh A, Tricia D Olsen, and Andrew G Reiter. 2011. "Transitional Justice Database Project." 2011. http://www.tjdbproject.com/, accessed 21 March 2013.

Peou, Sorpong. 2002. "Implementing Cambodia's Peace Agreement." In Ending Civil Wars:

The Implementation of Peace Agreements, edited by Stephen John Stedman, Donald

Rothchild, and Elizabeth M Cousens, 499-530. Boulder, CO: Lynne Rienner Publishers. Perry, Chris, and Adam C. Smith. 2013. Trends in Uniformed Contributions to UN

Peacekeeping: A New Dataset. New York: International Peace Institute. www.ipinst.org, 
accessed 22 July 2015.

Powell, Robert. 2002. "Bargaining Theory and International Conflict." Annual Review of Political Science 5 (1): 1-30.

Putnam, Tonya. 2002. "Human Rights and Sustainable Peace.” In Ending Civil Wars: The Implementation of Peace Agreements, edited by Stephen John Stedman, Donald Rothchild, and Elizabeth M Cousens, 237-72. Boulder, CO: Lynne Rienner Publishers. Reiter, Andrew G. 2014. "Examining the Use of Amnesties and Pardons as a Response to Internal Armed Conflict." Israel Law Review 47 (1): 144-47.

Reiter, Andrew G, Tricia D Olsen, and Leigh A Payne. 2012. "Transitional Justice and Civil War: Exploring New Pathways, Challenging Old Guideposts." Transitional Justice Review 1 (1): 137-69.

Roht-Arriaza, Naomi. 1990. "State Responsibility to Investigate and Prosecute Grave Human Rights Violations in International Law." California Law Review 78 (2): 449-514.

- 2006. "The New Landscape of Transitional Justice." In Transitional Justice in the Twenty-First Century: Beyond Truth versus Justice, edited by Naomi Roht-Arriaza and Javier Mariezcurrena, 1-16. New York: Cambridge University Press.

Ross, M L. 2004. "What Do We Know about Natural Resources and Civil War?" Journal of Peace Research 41 (3): 337-56.

Ryckman, Kirssa Cline. 2017. "Lasting Peace or Temporary Calm? Rebel Group

Decapitation and Civil War Outcomes." Conflict Management and Peace Science, no. forthcoming (September). https://doi.org/10.1177/0738894217724135.

Scharf, Michael P. 1996. "Swapping Amnesty for Peace: Was There a Duty to Prosecute International Crimes in Haiti." Texas International Law Journal 31 (1): 1-41.

Schomerus, Mareike, and Betty Acan Ogwaro. 2010. "Searching for Solutions in Juba: An Overview (2010)." Accord.

Schulhofer-Wohl, Jonah. 2007. "Algeria (1992-Present)." In Civil Wars of the World: Major Conflicts since World War II, edited by Karl R. DeRouen and Uk Heo, 103-24. Santa Barbara: ABC-CLIO.

Sikkink, Kathryn. 2012. "The Age of Accountability: The Global Rise of Individual Criminal Accountability." In Amnesty in the Age of Human Rights Accountability, edited by Francesca Lessa and Leigh A. Payne, 19-41. Cambridge: Cambridge University Press. Simmons, Beth A, and Allison Danner. 2010. "Credible Commitments and the International Criminal Court.” International Organization 64 (2): 225-56.

Skaar, Elin. 2012. "Reconciliation in a Transitional Justice Perspective." Transitional Justice Review 1 (1): 54-103.

Snyder, Jack, and Leslie Vinjamuri. 2003. "Trials and Errors: Principles and Pragmatism in Strategies of International Justice." International Security 28 (3): 5-44.

Sriram, Chandra Lekha. 2004. Confronting Past Human Rights Violations: Justice vs. Peace in Times of Transition. New York: Frank Cass.

Sutter, Daniel. 1995. "Settling Old Scores: Potholes along the Transition from Authoritarian Rule." Journal of Conflict Resolution 39 (1): 110-28.

Themner, Lotta, and Peter Wallensteen. 2012. “Armed Conflicts, 1946-2011." Journal of

Peace Research 49 (4): 565-75.

Tlemcani, Rachid. 2008. “Algeria under Boutiflika.” Carnegie Endowment for Peace. 
UN Secretary-General. 1999. "Seventh Report of the Secretary-General on the United Nations Observer Mission in Sierra Leone.” Vol. S/1999/836. New York: United Nations.

United Nations. n.d. "Peace Agreements Database.” Accessed May 1, 2015. peacemaker.un.org.

Vinjamuri, Leslie, and Jack Snyder. 2004. "Advocacy and Scholarship in the Study of International War Crimes Tribunals and Transitional Justice." Annual Review of Political Science 7: 345-62.

Walter, Barbara F. 1997. "The Critical Barrier to Civil War Settlement.” International Organization 51 (3): 335-64.

- 2002. Committing to Peace: The Successful Settlement of Civil Wars. Princeton, NJ: Princeton University Press.

- 2006. "Building Reputation: Why Governments Fight Some Separatists But Not Others.” American Journal of Political Science 50 (2): 313-30. 


\section{How and when amnesty during conflict affects conflict termination APPENDIX}

Table A1: Summary statistics

\begin{tabular}{lcclll}
\hline Variable & Obs & Mean & Std. Dev. & Min & Max \\
\hline Conflict ending & 1,917 & .6181534 & 1.301695 & 0 & 4 \\
Amnesty & 1,917 & .1403234 & .3474129 & 0 & 1 \\
$\begin{array}{l}\text { Disaggregated amnesty for } \\
\text { heinous crimes }\end{array}$ & 1,808 & .0973451 & .3620541 & 0 & 2 \\
$\begin{array}{l}\text { Disaggregated } \\
\text { formal/informal amnesties }\end{array}$ & 1,917 & .2070944 & .5458056 & 0 & 2 \\
Amnesty to other groups, & 1,401 & .0785153 & .2690769 & 0 & 1 \\
lagged & & & & & \\
Amnesty to other groups, & 1,401 & .152748 & .3598729 & 0 & 1 \\
previous 3 years & & & & & \\
Number of dyads & 1,917 & 1.777256 & 1.305578 & 1 & 8 \\
Rebel strength & 1,794 & 1.651059 & .6907738 & 1 & 5 \\
Incompatibility over & 1,911 & .4390372 & .4963995 & 0 & 1 \\
territory & & & & & \\
Intensity & 1,815 & 1.204408 & .4033793 & 1 & 2 \\
Resources in conflict area & 1,905 & .5501312 & .4976111 & 0 & 1 \\
Democracy, lag & 1,908 & .3463856 & .2434868 & .014593 & .9314962 \\
GDPpc, log, lag & 1,696 & 7.500791 & .9490107 & 5.330478 & 10.3532 \\
Post-Cold War & 1,917 & .5706834 & .4951078 & 0 & 1 \\
$\begin{array}{l}\text { Duration } \\
\text { UN Peace Keeping }\end{array}$ & 1,917 & 6.777256 & 6.467192 & 1 & 37 \\
Operation, lag & 1,425 & .0968421 & .2958465 & 0 & 1 \\
One-sided violence & 1,204 & 89.99585 & 902.6285 & 0 & 30110 \\
& & & & & \\
\hline
\end{tabular}


Table A2: Effect of amnesties on negotiated settlement only (other forms of termination not reported): Generous amnesty in interaction with post-2002

\begin{tabular}{|c|c|}
\hline & $\begin{array}{l}\text { Model } 1 \\
\mathrm{~b} / \mathrm{se}\end{array}$ \\
\hline \multicolumn{2}{|l|}{$\underline{\text { Negotiated settlement }}$} \\
\hline \multirow{2}{*}{$\begin{array}{l}\text { Amnesty for heinous } \\
\text { crime }\end{array}$} & -0.513 \\
\hline & $(0.44)$ \\
\hline \multirow{2}{*}{$\begin{array}{l}\text { Amnesty non-heinous } \\
\text { crime }\end{array}$} & 0.261 \\
\hline & $(0.63)$ \\
\hline \multirow[t]{2}{*}{ Post-2002 } & $0.498 *$ \\
\hline & $(0.29)$ \\
\hline \multirow{2}{*}{$\begin{array}{l}\text { Interaction: amnesty for } \\
\text { heinous crime and post- } \\
2002\end{array}$} & 0.928 \\
\hline & $(0.87)$ \\
\hline \multirow{2}{*}{$\begin{array}{l}\text { Interaction: amnesty non- } \\
\text { heinous crime and post- } \\
2002\end{array}$} & -0.499 \\
\hline & $(1.29)$ \\
\hline \multirow[t]{2}{*}{ Rebel strength } & $0.733 * * *$ \\
\hline & $(0.15)$ \\
\hline \multirow[t]{2}{*}{ Incompatibility territory } & 0.187 \\
\hline & $(0.28)$ \\
\hline \multirow[t]{2}{*}{ Intensity } & $-0.577 *$ \\
\hline & $(0.34)$ \\
\hline \multirow[t]{2}{*}{ Resources } & -0.198 \\
\hline & $(0.23)$ \\
\hline \multirow[t]{2}{*}{ Democracy lag } & $1.738 * * *$ \\
\hline & $(0.54)$ \\
\hline \multirow[t]{2}{*}{ GDPpc log lag } & $-0.396 * * *$ \\
\hline & $(0.15)$ \\
\hline \multirow[t]{2}{*}{ Duration } & $-0.308 * *$ \\
\hline & $(0.13)$ \\
\hline \multirow[t]{2}{*}{ Duration squared } & $0.029 * *$ \\
\hline & $(0.01)$ \\
\hline \multirow[t]{2}{*}{ Duration cubed } & $-0.001 * *$ \\
\hline & $(0.00)$ \\
\hline \multirow[t]{2}{*}{ Constant } & -0.100 \\
\hline & $(1.17)$ \\
\hline Observations & 1426 \\
\hline Pseudologlikelihood & -970.055 \\
\hline AIC & 2060.110 \\
\hline $\mathrm{BIC}$ & 2375.867 \\
\hline
\end{tabular}


Table A3: Effect of amnesties on different modes of conflict termination: UN Peace Keeping Operation included as a control variable

\begin{tabular}{|c|c|c|c|}
\hline & $\begin{array}{l}\text { Model } 1 \\
\text { b/se }\end{array}$ & $\begin{array}{l}\text { Model } 2 \\
\text { b/se }\end{array}$ & $\begin{array}{l}\text { Model } 3 \\
\text { b/se }\end{array}$ \\
\hline \multicolumn{4}{|l|}{ Negotiated settlement } \\
\hline Amnesty & $\begin{array}{l}-0.423 \\
(0.34)\end{array}$ & & \\
\hline $\begin{array}{l}\text { Amnesty for heinous } \\
\text { crime }\end{array}$ & & $\begin{array}{l}-0.708 \\
(0.49)\end{array}$ & \\
\hline $\begin{array}{l}\text { Amnesty non-heinous } \\
\text { crime }\end{array}$ & & $\begin{array}{l}-0.990 \\
(0.81)\end{array}$ & \\
\hline Formal amnesty & & & $\begin{array}{l}0.591^{*} \\
(0.34)\end{array}$ \\
\hline Informal amnesty & & & $\begin{array}{l}-0.728 \\
(0.62)\end{array}$ \\
\hline UN PKO lagged & $\begin{array}{l}0.244 \\
(0.47)\end{array}$ & $\begin{array}{l}0.230 \\
(0.50)\end{array}$ & $\begin{array}{l}0.177 \\
(0.50)\end{array}$ \\
\hline Rebel strength & $\begin{array}{l}0.756^{* * *} \\
(0.25)\end{array}$ & $\begin{array}{l}0.778 * * * \\
(0.25)\end{array}$ & $\begin{array}{l}0.688^{* * * *} \\
(0.26)\end{array}$ \\
\hline Incompatibility territory & $\begin{array}{l}0.764 * * \\
(0.34)\end{array}$ & $\begin{array}{l}0.611^{*} \\
(0.35)\end{array}$ & $\begin{array}{l}0.940 * * * \\
(0.35)\end{array}$ \\
\hline Intensity & $\begin{array}{l}-0.797 * \\
(0.43)\end{array}$ & $\begin{array}{l}-0.665 \\
(0.45)\end{array}$ & $\begin{array}{l}-0.676 \\
(0.43)\end{array}$ \\
\hline Resources & $\begin{array}{l}-0.219 \\
(0.29)\end{array}$ & $\begin{array}{l}-0.252 \\
(0.30)\end{array}$ & $\begin{array}{l}-0.239 \\
(0.30)\end{array}$ \\
\hline Democracy lag & $\begin{array}{l}-0.373 \\
(0.83)\end{array}$ & $\begin{array}{l}-0.375 \\
(0.88)\end{array}$ & $\begin{array}{l}-0.660 \\
(0.87)\end{array}$ \\
\hline GDPpc log lag & $\begin{array}{l}-0.473 * * \\
(0.22)\end{array}$ & $\begin{array}{l}-0.347 \\
(0.23)\end{array}$ & $\begin{array}{l}-0.458^{* *} \\
(0.23)\end{array}$ \\
\hline Duration & $\begin{array}{l}-0.343 \\
(0.23)\end{array}$ & $\begin{array}{l}-0.289 \\
(0.24)\end{array}$ & $\begin{array}{l}-0.279 \\
(0.23)\end{array}$ \\
\hline Duration squared & $\begin{array}{l}0.034 \\
(0.02)\end{array}$ & $\begin{array}{l}0.029 \\
(0.02)\end{array}$ & $\begin{array}{l}0.029 \\
(0.02)\end{array}$ \\
\hline Duration cubed & $\begin{array}{l}-0.001 \\
(0.00)\end{array}$ & $\begin{array}{l}-0.001 \\
(0.00)\end{array}$ & $\begin{array}{l}-0.001 \\
(0.00)\end{array}$ \\
\hline Constant & $\begin{array}{l}1.884 \\
(1.82)\end{array}$ & $\begin{array}{l}0.693 \\
(1.85)\end{array}$ & $\begin{array}{l}1.472 \\
(1.84)\end{array}$ \\
\hline \multicolumn{4}{|l|}{ Rebel victory } \\
\hline Amnesty & $\begin{array}{l}-1.376 \\
(1.02)\end{array}$ & & \\
\hline $\begin{array}{l}\text { Amnesty for heinous } \\
\text { crime }\end{array}$ & & N/A & \\
\hline $\begin{array}{l}\text { Amnesty non-heinous } \\
\text { crime }\end{array}$ & & N/A & \\
\hline Formal amnesty & & & N/A \\
\hline Informal amnesty & & & $\begin{array}{l}-0.285 \\
(1.13)\end{array}$ \\
\hline
\end{tabular}




\begin{tabular}{|c|c|c|c|}
\hline UK PKO lagged & $\begin{array}{l}-0.544 \\
(1.11)\end{array}$ & $\begin{array}{l}-0.621 \\
(1.08)\end{array}$ & $\begin{array}{l}-0.554 \\
(1.07)\end{array}$ \\
\hline Rebel strength & $\begin{array}{l}1.875^{* *} \\
(0.83)\end{array}$ & $\begin{array}{l}1.904 * * \\
(0.92)\end{array}$ & $\begin{array}{l}1.912 * * \\
(0.91)\end{array}$ \\
\hline Incompatibility territory & N/A & N/A & N/A \\
\hline Intensity & $\begin{array}{l}1.217 \\
(1.02)\end{array}$ & $\begin{array}{l}1.328 \\
(1.12)\end{array}$ & $\begin{array}{l}1.107 \\
(1.00)\end{array}$ \\
\hline Resources & $\begin{array}{l}-0.433 \\
(0.92)\end{array}$ & $\begin{array}{l}-0.651 \\
(0.96)\end{array}$ & $\begin{array}{l}-0.342 \\
(0.93)\end{array}$ \\
\hline Democracy lag & $\begin{array}{l}-3.836 \\
(2.87)\end{array}$ & $\begin{array}{l}-4.517 \\
(2.76)\end{array}$ & $\begin{array}{l}-4.328^{*} \\
(2.33)\end{array}$ \\
\hline GDPpc log lag & $\begin{array}{l}0.181 \\
(0.82)\end{array}$ & $\begin{array}{l}0.249 \\
(0.79)\end{array}$ & $\begin{array}{l}0.120 \\
(0.90)\end{array}$ \\
\hline Duration & $\begin{array}{l}-1.858 \\
(1.36)\end{array}$ & $\begin{array}{l}-2.115 \\
(1.32)\end{array}$ & $\begin{array}{l}-1.952 \\
(1.37)\end{array}$ \\
\hline Duration squared & $\begin{array}{l}0.255 \\
(0.17)\end{array}$ & $\begin{array}{l}0.306^{*} \\
(0.16)\end{array}$ & $\begin{array}{l}0.250 \\
(0.17)\end{array}$ \\
\hline Duration cubed & $\begin{array}{l}-0.010^{*} \\
(0.01)\end{array}$ & $\begin{array}{l}-0.012 * * \\
(0.01)\end{array}$ & $\begin{array}{l}-0.009 \\
(0.01)\end{array}$ \\
\hline Constant & $\begin{array}{l}-5.583 \\
(7.49)\end{array}$ & $\begin{array}{l}-5.624 \\
(7.25)\end{array}$ & $\begin{array}{l}-4.624 \\
(7.89)\end{array}$ \\
\hline Government victory & & & \\
\hline Amnesty & $\begin{array}{l}0.040 \\
(0.76)\end{array}$ & & \\
\hline $\begin{array}{l}\text { Amnesty for heinous } \\
\text { crime }\end{array}$ & & $\begin{array}{l}-0.070 \\
(1.05)\end{array}$ & \\
\hline $\begin{array}{l}\text { Amnesty non-heinous } \\
\text { crime }\end{array}$ & & $\begin{array}{l}1.233 \\
(0.93)\end{array}$ & \\
\hline Formal amnesty & & & $\begin{array}{l}-0.568 \\
(1.17)\end{array}$ \\
\hline Informal amnesty & & & $\begin{array}{l}0.483 \\
(0.79)\end{array}$ \\
\hline UN PKO lagged & $\begin{array}{l}1.236^{*} \\
(0.70)\end{array}$ & $\begin{array}{l}1.339^{*} \\
(0.75)\end{array}$ & $\begin{array}{l}1.253^{*} \\
(0.70)\end{array}$ \\
\hline Rebel strength & $\begin{array}{l}0.193 \\
(0.39)\end{array}$ & $\begin{array}{l}0.134 \\
(0.37)\end{array}$ & $\begin{array}{l}0.269 \\
(0.37)\end{array}$ \\
\hline Incompatibility territory & $\begin{array}{l}1.484 * \\
(0.88)\end{array}$ & $\begin{array}{l}1.502 * \\
(0.87)\end{array}$ & $\begin{array}{l}1.381 \\
(0.88)\end{array}$ \\
\hline Intensity & $\begin{array}{l}-1.108 \\
(1.02)\end{array}$ & $\begin{array}{l}-1.017 \\
(0.90)\end{array}$ & $\begin{array}{l}-1.148 \\
(0.97)\end{array}$ \\
\hline Resources & $\begin{array}{l}-0.962 \\
(0.77)\end{array}$ & $\begin{array}{l}-1.010 \\
(0.80)\end{array}$ & $\begin{array}{l}-0.862 \\
(0.74)\end{array}$ \\
\hline Democracy lag & $\begin{array}{l}-1.112 \\
(1.82)\end{array}$ & $\begin{array}{l}-1.017 \\
(1.66)\end{array}$ & $\begin{array}{l}-0.923 \\
(1.84)\end{array}$ \\
\hline GDPpc log lag & $\begin{array}{l}-0.709^{*} \\
(0.43)\end{array}$ & $\begin{array}{l}-0.817^{*} \\
(0.46)\end{array}$ & $\begin{array}{l}-0.730^{*} \\
(0.44)\end{array}$ \\
\hline Duration & $\begin{array}{l}-1.013^{*} \\
(0.57)\end{array}$ & $\begin{array}{l}-1.016^{*} \\
(0.56)\end{array}$ & $\begin{array}{l}-1.021^{*} \\
(0.58)\end{array}$ \\
\hline Duration squared & $0.075^{*}$ & $0.077 *$ & 0.075 \\
\hline
\end{tabular}




\begin{tabular}{llll}
\hline \multirow{3}{*}{ Duration cubed } & $(0.05)$ & $(0.04)$ & $(0.05)$ \\
& -0.001 & $-0.002^{*}$ & -0.001 \\
Constant & $(0.00)$ & $(0.00)$ & $(0.00)$ \\
& $4.998^{*}$ & $5.607^{* *}$ & $5.027^{*}$ \\
& $(2.98)$ & $(2.82)$ & $(2.99)$
\end{tabular}

\section{Go to low level}

\begin{tabular}{ll}
\hline Amnesty & $-0.686^{*}$ \\
& $(0.42)$
\end{tabular}

Amnesty for heinous

crime

Amnesty non-heinous
crime

crime

Formal amnesty

$(0.79)$

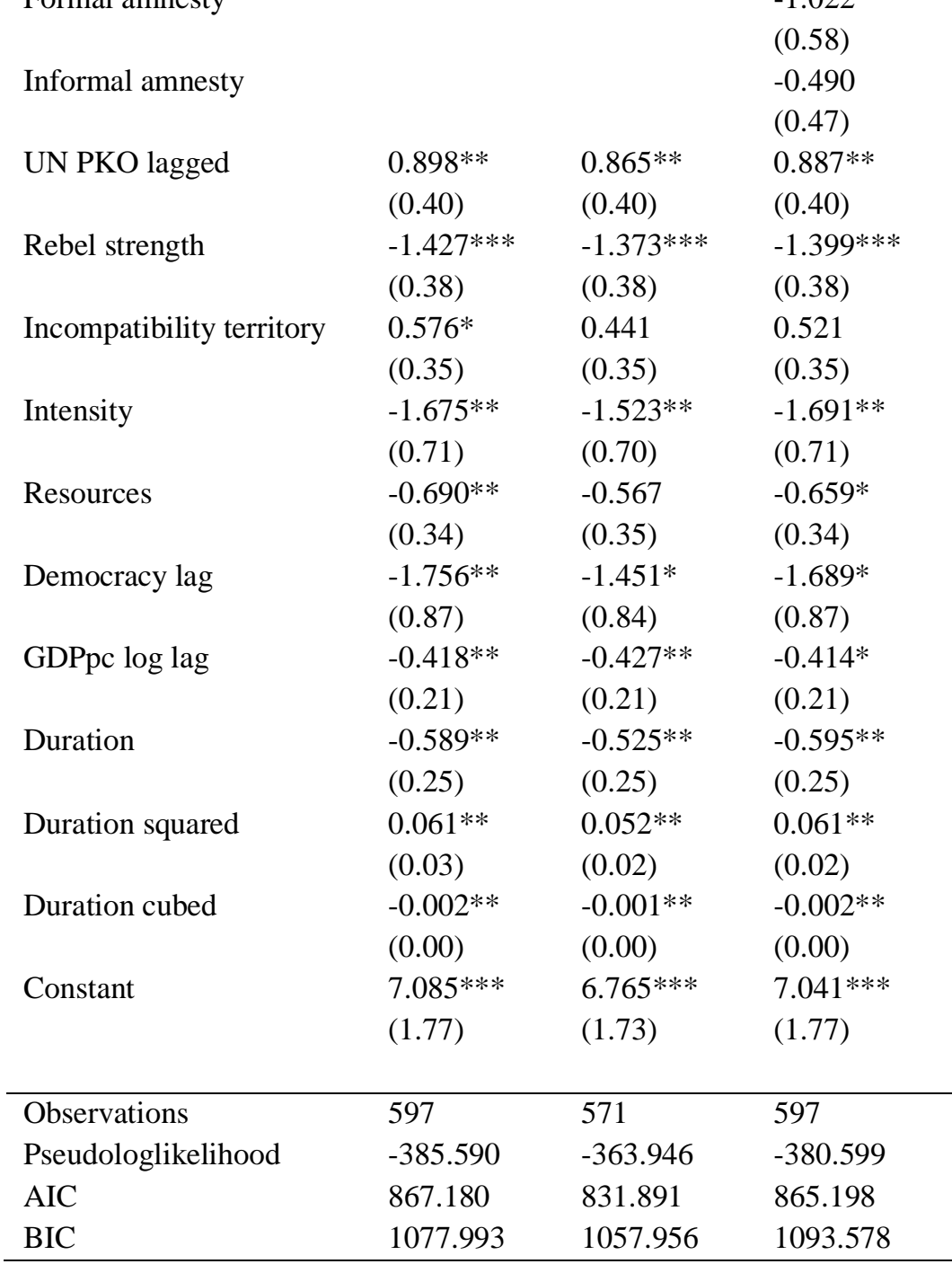

Significance: $* \mathrm{p}<0.1, * * \mathrm{p}<0.05, * * * \mathrm{p}<0.01$. Standard errors clustered on dyad reported in brackets. N/A: insufficient cases in the cell to compute reliable values (Multinomial logistic regression: stata data analysis examples, n.d.). Models 4 and 5 did not solve. 
Table A4: Effect of amnesties on different modes of conflict termination: one-sided violence included as a control variable

\begin{tabular}{|c|c|c|c|}
\hline & $\begin{array}{l}\text { Model } 1 \\
\text { b/se }\end{array}$ & $\begin{array}{l}\text { Model } 2 \\
\text { b/se }\end{array}$ & $\begin{array}{l}\text { Model } 3 \\
\text { b/se }\end{array}$ \\
\hline \multicolumn{4}{|l|}{ Negotiated settlement } \\
\hline Amnesty & $\begin{array}{l}-0.088 \\
(0.27)\end{array}$ & & \\
\hline $\begin{array}{l}\text { Amnesty for heinous } \\
\text { crime }\end{array}$ & & $\begin{array}{l}-0.184 \\
(0.40)\end{array}$ & \\
\hline $\begin{array}{l}\text { Amnesty non-heinous } \\
\text { crime }\end{array}$ & & $\begin{array}{l}-0.240 \\
(0.60)\end{array}$ & \\
\hline Formal amnesty & & & $\begin{array}{l}0.812 * * * \\
(0.29)\end{array}$ \\
\hline Informal amnesty & & & $\begin{array}{l}-0.494 \\
(0.48)\end{array}$ \\
\hline One-sided violence & $\begin{array}{l}-0.001 \\
(0.00)\end{array}$ & $\begin{array}{l}-0.001 \\
(0.00)\end{array}$ & $\begin{array}{l}-0.001 \\
(0.00)\end{array}$ \\
\hline Rebel strength & $\begin{array}{l}0.750 * * * \\
(0.18)\end{array}$ & $\begin{array}{l}0.752 * * * \\
(0.19)\end{array}$ & $\begin{array}{l}0.733 * * * \\
(0.19)\end{array}$ \\
\hline Incompatibility territory & $\begin{array}{l}0.589 * * \\
(0.29)\end{array}$ & $\begin{array}{l}0.538^{*} \\
(0.30)\end{array}$ & $\begin{array}{l}0.697 * * \\
(0.29)\end{array}$ \\
\hline Intensity & $\begin{array}{l}-0.779 * * \\
(0.39)\end{array}$ & $\begin{array}{l}-0.686^{*} \\
(0.41)\end{array}$ & $\begin{array}{l}-0.750^{*} \\
(0.39)\end{array}$ \\
\hline Resources & $\begin{array}{l}-0.215 \\
(0.23)\end{array}$ & $\begin{array}{l}-0.255 \\
(0.24)\end{array}$ & $\begin{array}{l}-0.258 \\
(0.23)\end{array}$ \\
\hline Democracy lag & $\begin{array}{l}0.605 \\
(0.64)\end{array}$ & $\begin{array}{l}0.742 \\
(0.66)\end{array}$ & $\begin{array}{l}0.581 \\
(0.65)\end{array}$ \\
\hline GDPpc log lag & $\begin{array}{l}-0.399 * * \\
(0.17)\end{array}$ & $\begin{array}{l}-0.364^{* *} \\
(0.17)\end{array}$ & $\begin{array}{l}-0.384 * * \\
(0.17)\end{array}$ \\
\hline Post-Cold War & $\begin{array}{l}0.817 * \\
(0.44)\end{array}$ & $\begin{array}{l}0.711 \\
(0.45)\end{array}$ & $\begin{array}{l}0.765^{*} \\
(0.46)\end{array}$ \\
\hline Duration & $\begin{array}{l}-0.270^{*} \\
(0.14)\end{array}$ & $\begin{array}{l}-0.277^{*} \\
(0.15)\end{array}$ & $\begin{array}{l}-0.288^{* *} \\
(0.14)\end{array}$ \\
\hline Duration squared & $\begin{array}{l}0.024^{*} \\
(0.01)\end{array}$ & $\begin{array}{l}0.025^{*} \\
(0.01)\end{array}$ & $\begin{array}{l}0.026^{*} \\
(0.01)\end{array}$ \\
\hline Duration cubed & $\begin{array}{l}-0.001^{*} \\
(0.00)\end{array}$ & $\begin{array}{l}-0.001^{*} \\
(0.00)\end{array}$ & $\begin{array}{l}-0.001 * \\
(0.00)\end{array}$ \\
\hline Constant & $\begin{array}{l}0.184 \\
(1.28)\end{array}$ & $\begin{array}{l}-0.104 \\
(1.32)\end{array}$ & $\begin{array}{l}0.035 \\
(1.27)\end{array}$ \\
\hline \multicolumn{4}{|l|}{ Rebel victory } \\
\hline Amnesty & $\begin{array}{l}-0.730 \\
(0.67)\end{array}$ & & \\
\hline $\begin{array}{l}\text { Amnesty for heinous } \\
\text { crime }\end{array}$ & & N/A & \\
\hline $\begin{array}{l}\text { Amnesty non-heinous } \\
\text { crime }\end{array}$ & & N/A & \\
\hline Formal amnesty & & & -0.854 \\
\hline
\end{tabular}




\begin{tabular}{|c|c|c|c|}
\hline \multirow{2}{*}{\multicolumn{3}{|c|}{ Informal amnesty }} & $(0.99)$ \\
\hline & & & -0.807 \\
\hline \multirow[t]{2}{*}{ One-sided violence } & $-0.000 * *$ & $-0.000 * *$ & $-0.000 * *$ \\
\hline & $(0.00)$ & $(0.00)$ & $(0.00)$ \\
\hline \multirow[t]{2}{*}{ Rebel strength } & $1.759 * * *$ & $1.513 * *$ & $1.755^{* * *}$ \\
\hline & $(0.56)$ & $(0.66)$ & $(0.58)$ \\
\hline \multirow[t]{2}{*}{ Incompatibility territory } & -0.208 & -0.025 & -0.214 \\
\hline & $(1.23)$ & $(1.29)$ & $(1.22)$ \\
\hline \multirow[t]{2}{*}{ Intensity } & 0.596 & 0.761 & 0.599 \\
\hline & $(0.77)$ & $(0.83)$ & $(0.76)$ \\
\hline \multirow[t]{2}{*}{ Resources } & -0.460 & -0.930 & -0.417 \\
\hline & $(0.64)$ & $(0.63)$ & $(0.62)$ \\
\hline \multirow[t]{2}{*}{ Democracy lag } & -0.274 & -0.399 & -0.338 \\
\hline & $(2.48)$ & $(2.64)$ & $(2.43)$ \\
\hline \multirow{2}{*}{ GDPpc log lag } & -0.397 & -0.711 & -0.396 \\
\hline & $(0.49)$ & $(0.55)$ & $(0.51)$ \\
\hline Post-Cold War & N/A & N/A & N/A \\
\hline \multirow[t]{2}{*}{ Duration } & $-1.220 * *$ & $-1.095 * *$ & $-1.175^{* *}$ \\
\hline & $(0.51)$ & $(0.50)$ & $(0.54)$ \\
\hline \multirow[t]{2}{*}{ Duration squared } & $0.158 * *$ & $0.145 * *$ & $0.151^{*}$ \\
\hline & $(0.07)$ & $(0.07)$ & $(0.08)$ \\
\hline \multirow{2}{*}{ Duration cubed } & $-0.006 * *$ & $-0.005 * *$ & $-0.006^{*}$ \\
\hline & $(0.00)$ & $(0.00)$ & $(0.00)$ \\
\hline Constant & N/A & N/A & N/A \\
\hline \multicolumn{4}{|l|}{ Government victory } \\
\hline \multirow[t]{2}{*}{ Amnesty } & -0.053 & & \\
\hline & $(0.56)$ & & \\
\hline \multirow{2}{*}{$\begin{array}{l}\text { Amnesty for heinous } \\
\text { crime }\end{array}$} & & 0.348 & \\
\hline & & $(0.73)$ & \\
\hline \multirow{2}{*}{$\begin{array}{l}\text { Amnesty non-heinous } \\
\text { crime }\end{array}$} & & 0.802 & \\
\hline & & $(0.75)$ & \\
\hline \multirow[t]{2}{*}{ Formal amnesty } & & & -0.260 \\
\hline & & & $(0.78)$ \\
\hline \multirow[t]{2}{*}{ Informal amnesty } & & & -0.129 \\
\hline & & & $(0.73)$ \\
\hline \multirow[t]{2}{*}{ One-sided violence } & -0.004 & -0.005 & -0.004 \\
\hline & $(0.01)$ & $(0.01)$ & $(0.01)$ \\
\hline \multirow[t]{2}{*}{ Rebel strength } & 0.335 & $0.389 *$ & 0.331 \\
\hline & $(0.24)$ & $(0.24)$ & $(0.24)$ \\
\hline \multirow[t]{2}{*}{ Incompatibility territory } & $0.914 *$ & $0.967^{*}$ & $0.895^{*}$ \\
\hline & $(0.50)$ & $(0.50)$ & $(0.51)$ \\
\hline \multirow[t]{2}{*}{ Intensity } & -1.079 & $-1.159^{*}$ & -1.055 \\
\hline & $(0.68)$ & $(0.62)$ & $(0.70)$ \\
\hline \multirow[t]{2}{*}{ Resources } & -0.223 & -0.248 & -0.214 \\
\hline & $(0.40)$ & $(0.41)$ & $(0.40)$ \\
\hline \multirow[t]{2}{*}{ Democracy lag } & -0.988 & -0.959 & -0.994 \\
\hline & $(1.15)$ & (1.15) & $(1.14)$ \\
\hline GDPpc log lag & -0.154 & -0.141 & -0.149 \\
\hline
\end{tabular}




\begin{tabular}{llll}
\hline \multirow{3}{*}{ Post-Cold War } & $(0.26)$ & $(0.26)$ & $(0.25)$ \\
& 0.208 & 0.196 & 0.227 \\
Duration & $(0.57)$ & $(0.58)$ & $(0.57)$ \\
& $-1.023^{* * * *}$ & $-1.074^{* * *}$ & $-1.006^{* * *}$ \\
Duration squared & $(0.33)$ & $(0.32)$ & $(0.32)$ \\
\multirow{2}{*}{ Duration cubed } & $0.072^{* * *}$ & $0.076^{* * *}$ & $0.071^{* * *}$ \\
& $(0.03)$ & $(0.03)$ & $(0.03)$ \\
Constant & $-0.001^{* *}$ & $-0.001^{* * *}$ & $-0.001^{* *}$ \\
& $(0.00)$ & $(0.00)$ & $(0.00)$ \\
& 0.939 & 0.877 & 0.866 \\
& $(1.84)$ & $(1.91)$ & $(1.85)$
\end{tabular}

\section{Go to low level}

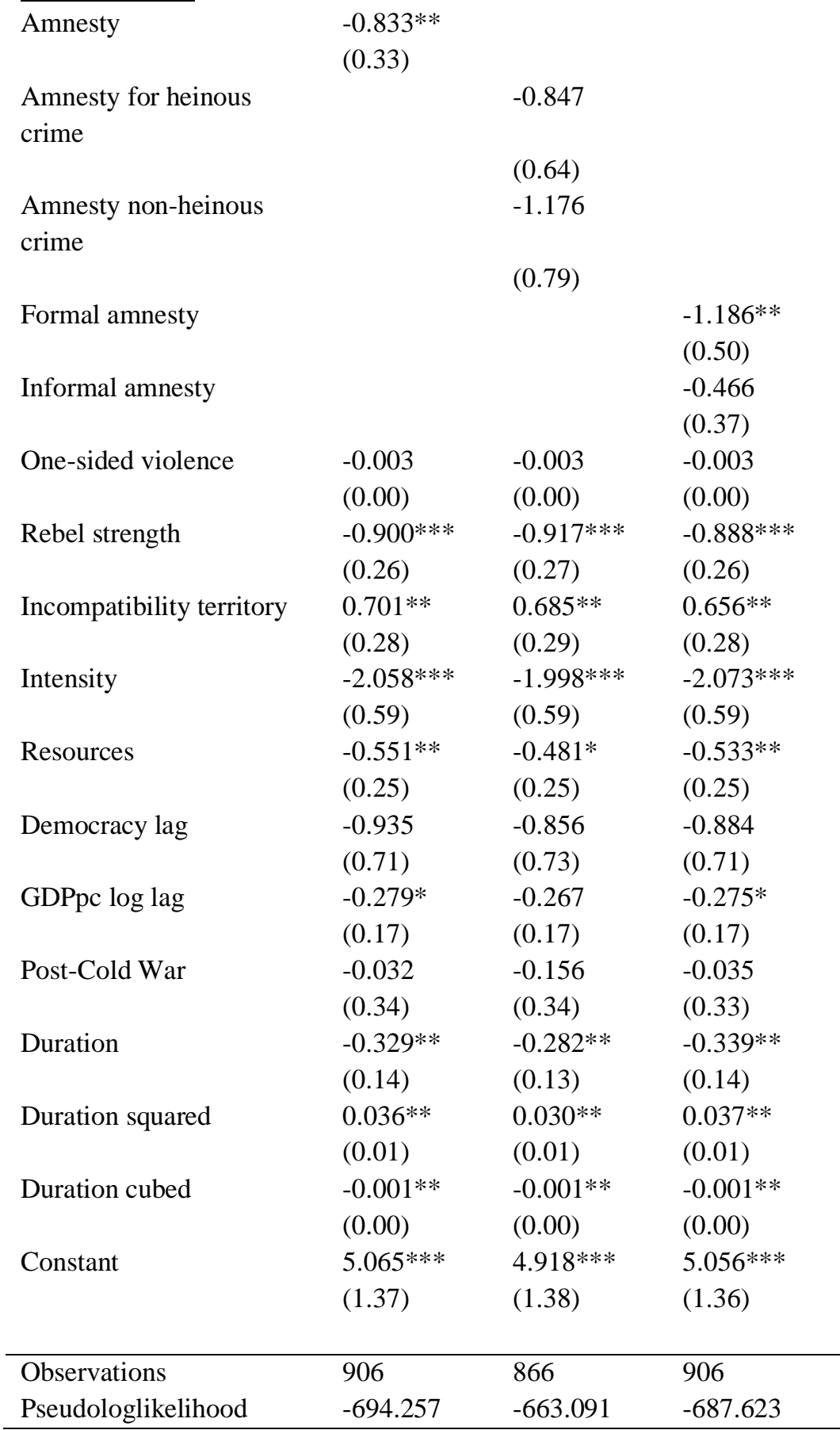




\begin{tabular}{llll}
\hline AIC & 1492.514 & 1438.181 & 1487.245 \\
BIC & 1742.584 & 1704.959 & 1756.552 \\
\hline
\end{tabular}

Significance: $* \mathrm{p}<0.1, * * \mathrm{p}<0.05, * * * \mathrm{p}<0.01$. Standard errors clustered on dyad reported in brackets. N/A: insufficient cases in the cell to compute reliable values (Multinomial logistic regression: stata data analysis examples, n.d.). Models 4 and 5 did not solve. 
Table A5: Effect of amnesties on different modes of conflict termination: without FARC

\section{Negotiated settlement}

Amnesty

$$
\begin{aligned}
& -0.105 \\
& (0.25)
\end{aligned}
$$

Model 2

Model 3

Model 4

Model 5

$\mathrm{b} / \mathrm{se}$

$\mathrm{b} / \mathrm{se}$

$\mathrm{b} / \mathrm{se}$

$\mathrm{b} / \mathrm{se}$

$\mathrm{b} / \mathrm{se}$

Amnesty for heinous

crime

Amnesty non-heinous

crime

Formal amnesty

Informal amnesty

$-0.416$

$\begin{array}{ll}-0.164 & -0.147 \\ (0.50) & (0.51)\end{array}$

(0.50)

(0.51)

(0.38)

0.041

$(0.56)$

$$
\begin{aligned}
& 0.701 * * * \\
& (0.26) \\
& -0.427 \\
& (0.43)
\end{aligned}
$$

Amnesty to other groups,

previous year

Amnesty to other groups,

previous 3 years

Rebel strength
Incompatibility territory

$0.713 * * *$

$0.700 * * *$

$0.718^{* * * *}$

$-1.100 *$

(0.64)

(0.15)

(0.16)

(0.16)

$1.291 * * *$

(0.29)

0.308

(0.54)

(0.27)

(0.28)

0.362

(0.54)

$-0.606^{*}$

$-0.603^{*}$

(0.31)

$-1.329 *$

(0.31)

(0.33)

$-0.200$

(0.69)

0.083

(0.53)

(0.21)

(0.22)

Democracy lag

$0.960 *$

$1.030 *$

$(0.22)$

$0.991 *$

$-1.542$

(0.58)

(1.42)

$-0.274 *$

0.086

$1.158 * *$

-0.280 **

$-0.273^{*}$

(0.14)

(0.31)

(0.58)

(0.14)

(0.15)

Post-Cold War

$1.305^{* * *}$

$1.242 * * *$

$1.290 * * *$

$1.626 * * *$

$1.221 * * *$

(0.30)

(0.30)

(0.30)

(0.54)

(0.30)

0.234

(0.54)

$-1.298 *$

Number of dyads

Duration

$-0.287 * *$

$-0.286 * *$

$-0.296^{* *}$

0.030

(0.69)

0.067

(0.52)

$-1.086$

(1.39)

$-0.001$

Duration squared

(0.13)

(0.14)

(0.13)

(0.16)

$(0.29)$

$0.026 * *$

0.027 *

$0.027 * *$

$-0.308$

$1.574 * * *$

(0.01)

(0.01)

$(0.01)$

(0.41)

0.017

(0.52)

Duration cubed

$-0.001 *$

$-0.001 *$

$-0.001 *$

(0.04)

0.040

(0.00)

(0.00)

(0.00)

$-0.000$

(0.16)

Constant

$-1.361$

$-1.407$

$-1.549$

(0.00)

$-0.258$

(0.40)

0.012

(0.04)

(1.11)

(1.16)

(1.11)

$-3.509$

0.000

(0.00)

$-2.868$

(2.89)

(2.76)

\section{Rebel victory}




\begin{tabular}{|c|c|c|c|c|c|}
\hline \multicolumn{2}{|l|}{$\begin{array}{l}\text { Amnesty for heinous } \\
\text { crime }\end{array}$} & \multicolumn{4}{|l|}{-1.007} \\
\hline $\begin{array}{l}\text { Amnesty non-heinous } \\
\text { crime }\end{array}$ & & N/A & & & \\
\hline Formal amnesty & & & $\begin{array}{l}-0.566 \\
(0.81)\end{array}$ & & \\
\hline Informal amnesty & & & $\begin{array}{l}-1.146 \\
(0.87)\end{array}$ & & \\
\hline Rebel strength & $\begin{array}{l}1.154 * * * \\
(0.32)\end{array}$ & $\begin{array}{l}1.033^{* * *} \\
(0.35)\end{array}$ & $\begin{array}{l}1.162 * * * \\
(0.33)\end{array}$ & & \\
\hline Incompatibility territory & $\begin{array}{l}-0.633 \\
(0.91)\end{array}$ & $\begin{array}{l}-0.545 \\
(0.91)\end{array}$ & $\begin{array}{l}-0.638 \\
(0.91)\end{array}$ & & \\
\hline Intensity & $\begin{array}{l}0.646 \\
(0.51)\end{array}$ & $\begin{array}{l}0.730 \\
(0.51)\end{array}$ & $\begin{array}{l}0.652 \\
(0.50)\end{array}$ & & \\
\hline Resources & $\begin{array}{l}-0.558 \\
(0.49)\end{array}$ & $\begin{array}{l}-0.833^{*} \\
(0.46)\end{array}$ & $\begin{array}{l}-0.551 \\
(0.49)\end{array}$ & & \\
\hline Democracy lag & $\begin{array}{l}-1.265 \\
(1.77)\end{array}$ & $\begin{array}{l}-1.489 \\
(1.89)\end{array}$ & $\begin{array}{l}-1.214 \\
(1.76)\end{array}$ & & \\
\hline GDPpc log lag & $\begin{array}{l}-0.573 \\
(0.44)\end{array}$ & $\begin{array}{l}-0.787^{*} \\
(0.44)\end{array}$ & $\begin{array}{l}-0.584 \\
(0.44)\end{array}$ & & \\
\hline Post-Cold War & $\begin{array}{l}0.873 * \\
(0.51)\end{array}$ & $\begin{array}{l}0.759 \\
(0.49)\end{array}$ & $\begin{array}{l}0.880^{*} \\
(0.51)\end{array}$ & & \\
\hline Duration & $\begin{array}{l}-0.537 \\
(0.40)\end{array}$ & $\begin{array}{l}-0.447 \\
(0.40)\end{array}$ & $\begin{array}{l}-0.530 \\
(0.41)\end{array}$ & & \\
\hline Duration squared & $\begin{array}{l}0.055 \\
(0.06)\end{array}$ & $\begin{array}{l}0.044 \\
(0.06)\end{array}$ & $\begin{array}{l}0.056 \\
(0.06)\end{array}$ & & \\
\hline Duration cubed & $\begin{array}{l}-0.002 \\
(0.00)\end{array}$ & $\begin{array}{l}-0.002 \\
(0.00)\end{array}$ & $\begin{array}{l}-0.002 \\
(0.00)\end{array}$ & & \\
\hline Constant & $\begin{array}{l}-1.532 \\
(3.37)\end{array}$ & $\begin{array}{l}0.200 \\
(3.18)\end{array}$ & $\begin{array}{l}-1.495 \\
(3.40)\end{array}$ & & \\
\hline Government victory & & & & & \\
\hline Amnesty & $\begin{array}{l}-0.321 \\
(0.46)\end{array}$ & & & $\begin{array}{l}0.846 \\
(1.73)\end{array}$ & $\begin{array}{l}0.426 \\
(1.51)\end{array}$ \\
\hline $\begin{array}{l}\text { Amnesty for heinous } \\
\text { crime }\end{array}$ & & $\begin{array}{l}0.005 \\
(0.60)\end{array}$ & & & \\
\hline $\begin{array}{l}\text { Amnesty non-heinous } \\
\text { crime }\end{array}$ & & $\begin{array}{l}0.740 \\
(0.67)\end{array}$ & & & \\
\hline Formal amnesty & & & $\begin{array}{l}-0.554 \\
(0.63)\end{array}$ & & \\
\hline Informal amnesty & & & $\begin{array}{l}-0.288 \\
(0.60)\end{array}$ & & \\
\hline $\begin{array}{l}\text { Amnesty to other groups, } \\
\text { previous year }\end{array}$ & & & & $\begin{array}{l}-0.836 \\
(1.98)\end{array}$ & \\
\hline $\begin{array}{l}\text { Amnesty to other groups, } \\
\text { previous } 3 \text { years }\end{array}$ & & & & & $\begin{array}{l}0.058 \\
(1.45)\end{array}$ \\
\hline Rebel strength & -0.106 & -0.046 & -0.112 & 0.007 & 0.078 \\
\hline
\end{tabular}




\begin{tabular}{|c|c|c|c|c|c|}
\hline & $(0.28)$ & $(0.26)$ & $(0.28)$ & $(0.98)$ & $(1.02)$ \\
\hline \multirow[t]{2}{*}{ Incompatibility territory } & -0.013 & 0.041 & -0.038 & N/A & N/A \\
\hline & $(0.40)$ & $(0.41)$ & $(0.41)$ & & \\
\hline \multirow[t]{2}{*}{ Intensity } & -0.585 & -0.645 & -0.565 & -0.027 & 0.083 \\
\hline & $(0.50)$ & $(0.46)$ & $(0.50)$ & $(0.88)$ & $(0.83)$ \\
\hline \multirow[t]{2}{*}{ Resources } & $-0.630 *$ & $-0.668^{*}$ & $-0.625^{*}$ & 0.795 & 0.733 \\
\hline & $(0.35)$ & $(0.36)$ & $(0.35)$ & $(1.78)$ & $(1.91)$ \\
\hline \multirow[t]{2}{*}{ Democracy lag } & -1.171 & -1.206 & -1.190 & $-4.189 *$ & -4.190 \\
\hline & $(0.94)$ & $(0.96)$ & $(0.93)$ & $(2.39)$ & $(2.66)$ \\
\hline \multirow{2}{*}{ GDPpc log lag } & 0.130 & 0.154 & 0.129 & 0.573 & 0.593 \\
\hline & $(0.22)$ & $(0.22)$ & $(0.22)$ & $(0.97)$ & (1.07) \\
\hline \multirow[t]{2}{*}{ Post-Cold War } & 0.549 & 0.502 & 0.553 & 0.360 & 0.273 \\
\hline & $(0.35)$ & $(0.35)$ & $(0.35)$ & $(1.22)$ & $(1.16)$ \\
\hline \multirow[t]{2}{*}{ Number of dyads } & & & & -1.801 & -1.819 \\
\hline & & & & $(1.24)$ & $(1.44)$ \\
\hline \multirow[t]{2}{*}{ Duration } & $-0.964 * * *$ & $-1.008 * * *$ & $-0.956 * * *$ & $-7.635^{*}$ & -7.602 \\
\hline & $(0.23)$ & $(0.23)$ & $(0.23)$ & $(4.54)$ & $(4.91)$ \\
\hline \multirow[t]{2}{*}{ Duration squared } & $0.067 * * *$ & $0.071 * * *$ & $0.066 * * *$ & $1.584^{*}$ & 1.574 \\
\hline & $(0.02)$ & $(0.02)$ & $(0.02)$ & $(0.96)$ & (1.04) \\
\hline \multirow[t]{2}{*}{ Duration cubed } & $-0.001 * * *$ & $-0.001 * * *$ & $-0.001 * * *$ & -0.097 & -0.096 \\
\hline & $(0.00)$ & $(0.00)$ & $(0.00)$ & $(0.06)$ & $(0.07)$ \\
\hline \multirow[t]{2}{*}{ Constant } & -0.834 & -0.969 & -0.818 & 7.198 & 6.832 \\
\hline & $(1.82)$ & $(1.85)$ & $(1.82)$ & (12.36) & (12.60) \\
\hline \multicolumn{6}{|l|}{ Go to low level } \\
\hline \multirow[t]{2}{*}{$\overline{\text { Amnesty }}$} & $-0.612 * *$ & & & $-1.269 * *$ & -0.642 \\
\hline & $(0.27)$ & & & $(0.58)$ & $(0.41)$ \\
\hline \multirow{2}{*}{$\begin{array}{l}\text { Amnesty for heinous } \\
\text { crime }\end{array}$} & & $-0.892 *$ & & & \\
\hline & & $(0.50)$ & & & \\
\hline \multirow{2}{*}{$\begin{array}{l}\text { Amnesty non-heinous } \\
\text { crime }\end{array}$} & & -0.981 & & & \\
\hline & & $(0.64)$ & & & \\
\hline \multirow[t]{2}{*}{ Formal amnesty } & & & $-0.722 * *$ & & \\
\hline & & & $(0.33)$ & & \\
\hline \multirow[t]{2}{*}{ Informal amnesty } & & & -0.499 & & \\
\hline & & & $(0.34)$ & & \\
\hline \multirow{2}{*}{$\begin{array}{l}\text { Amnesty to other groups, } \\
\text { previous year }\end{array}$} & & & & $1.517 * * *$ & \\
\hline & & & & $(0.51)$ & \\
\hline \multirow{2}{*}{$\begin{array}{l}\text { Amnesty to other groups, } \\
\text { previous } 3 \text { years }\end{array}$} & & & & & $0.784 * *$ \\
\hline & & & & & $(0.36)$ \\
\hline \multirow[t]{2}{*}{ Rebel strength } & $-0.758 * * *$ & $-0.757 * * *$ & $-0.755^{* * *}$ & -0.589 & -0.579 \\
\hline & $(0.23)$ & $(0.24)$ & $(0.23)$ & $(0.41)$ & $(0.42)$ \\
\hline \multirow[t]{2}{*}{ Incompatibility territory } & 0.177 & 0.141 & 0.159 & $0.951 * *$ & $0.977 * *$ \\
\hline & $(0.23)$ & $(0.24)$ & $(0.23)$ & $(0.48)$ & $(0.45)$ \\
\hline \multirow[t]{2}{*}{ Intensity } & $-1.883 * * *$ & $-1.821 * * *$ & $-1.889 * * *$ & $-2.007 * *$ & $-2.099 * *$ \\
\hline & $(0.47)$ & $(0.47)$ & $(0.47)$ & $(0.82)$ & $(0.84)$ \\
\hline \multirow[t]{2}{*}{ Resources } & $-0.478 * *$ & $-0.432 * *$ & $-0.470 * *$ & $-1.171 * * *$ & $-1.139 * * *$ \\
\hline & $(0.21)$ & $(0.22)$ & $(0.21)$ & $(0.41)$ & $(0.41)$ \\
\hline Democracy lag & -0.889 & -0.792 & -0.871 & 0.806 & 0.586 \\
\hline
\end{tabular}




\begin{tabular}{|c|c|c|c|c|c|}
\hline & $(0.55)$ & $(0.55)$ & $(0.55)$ & $(0.89)$ & $(0.88)$ \\
\hline \multirow[t]{2}{*}{ GDPpc log lag } & -0.142 & -0.145 & -0.142 & $-0.584 * *$ & $-0.529 * *$ \\
\hline & $(0.13)$ & $(0.13)$ & $(0.13)$ & $(0.27)$ & $(0.27)$ \\
\hline \multirow[t]{2}{*}{ Post-Cold War } & $0.680 * * *$ & $0.643 * * *$ & $0.682 * * *$ & -0.052 & -0.023 \\
\hline & $(0.24)$ & $(0.24)$ & $(0.24)$ & $(0.45)$ & $(0.47)$ \\
\hline \multirow[t]{2}{*}{ Number of dyads } & & & & 0.147 & 0.124 \\
\hline & & & & $(0.13)$ & $(0.14)$ \\
\hline \multirow[t]{2}{*}{ Duration } & $-0.304 * * *$ & $-0.273 * *$ & $-0.307 * * *$ & -0.129 & -0.211 \\
\hline & $(0.12)$ & $(0.11)$ & $(0.12)$ & $(0.36)$ & $(0.37)$ \\
\hline \multirow[t]{2}{*}{ Duration squared } & $0.032 * *$ & $0.028 * *$ & $0.032 * *$ & 0.004 & 0.011 \\
\hline & $(0.01)$ & $(0.01)$ & $(0.01)$ & $(0.04)$ & $(0.04)$ \\
\hline \multirow[t]{2}{*}{ Duration cubed } & $-0.001 * *$ & $-0.001 * *$ & $-0.001 * *$ & 0.000 & -0.000 \\
\hline & $(0.00)$ & $(0.00)$ & $(0.00)$ & $(0.00)$ & $(0.00)$ \\
\hline \multirow[t]{2}{*}{ Constant } & $3.039 * * *$ & $2.959 * * *$ & $3.051 * * *$ & $5.589 * *$ & $5.443 * *$ \\
\hline & $(1.13)$ & $(1.13)$ & $(1.12)$ & $(2.58)$ & $(2.57)$ \\
\hline Observations & 1476 & 1391 & 1476 & 459 & 459 \\
\hline Pseudologlikelihood & -995.927 & -954.858 & -990.172 & -261.261 & -261.093 \\
\hline AIC & 2087.853 & 2013.717 & 2084.343 & 634.521 & 634.187 \\
\hline BIC & 2342.114 & 2286.081 & 2359.792 & 865.748 & 865.414 \\
\hline
\end{tabular}

Significance: $* \mathrm{p}<0.1, * * \mathrm{p}<0.05, * * * \mathrm{p}<0.01$. Standard errors clustered on dyad reported in brackets. N/A: insufficient cases in the cell to compute reliable values (Multinomial logistic regression: stata data analysis examples, n.d.).

\section{$\underline{\text { References }}$}

Multinomial logistic regression: stata data analysis examples (n.d.). UCLA: Statistical Consulting Group (https://stats.idre.ucla.edu/stata/dae/multinomiallogistic-regression/). 